\title{
Budgeting suspended sediment fluxes in tropical monsoonal watersheds with limited data: the Lake Tana basin
}

\author{
Fasikaw A. Zimale ${ }^{1}$, Mamaru A. Moges ${ }^{1}$, Muluken L. Alemu ${ }^{1}$, Essayas K. Ayana ${ }^{2,3}$, \\ Solomon S. Demissie ${ }^{4}$, Seifu A. Tilahun ${ }^{2}$, Tammo S. Steenhuis ${ }^{2,5^{*}}$ \\ ${ }^{1}$ Faculty of Civil and Water Resources Engineering, PhD program in Integrated Water Management, Bahir Dar Institute of Technology, \\ Bahir Dar University, Bahir Dar, Ethiopia. \\ ${ }^{2}$ Faculty of Civil and Water Resources Engineering, Bahir Dar Institute of Technology, Bahir Dar University, Bahir Dar, Ethiopia. \\ ${ }^{3}$ Department of Ecology, Evolution and Environmental Biology, Columbia University, New York, NY, USA. \\ ${ }^{4}$ Ethiopian Institute of Water Resources, Addis Ababa, Ethiopia. \\ ${ }^{5}$ Department of Biological and Environmental Engineering, 206 Riley Robb Hall, Cornell University, Ithaca NY 14853 USA. \\ ${ }^{*}$ Corresponding author. E-mail: tss1@cornell.edu
}

\begin{abstract}
Soil erosion decreases soil fertility of the uplands and causes siltation of lakes and reservoirs; the lakes and reservoirs in tropical monsoonal African highlands are especially affected by sedimentation. Efforts in reducing loads by designing management practices are hampered by lack of quantitative data on the relationship of erosion in the watersheds and sediment accumulation on flood plains, lakes and reservoirs. The objective of this study is to develop a prototype quantitative method for estimating sediment budget for tropical monsoon lakes with limited observational data. Four watersheds in the Lake Tana basin were selected for this study. The Parameter Efficient Distributed (PED) model that has shown to perform well in the Ethiopian highlands is used to overcome the data limitations and recreate the missing sediment fluxes. PED model parameters are calibrated using daily discharge data and the occasionally collected sediment concentration when establishing the sediment rating curves for the major rivers. The calibrated model parameters are then used to predict the sediment budget for the 1994-2009 period. Sediment retained in the lake is determined from two bathymetric surveys taken 20 years apart whereas the sediment leaving the lake is calculated based on measured discharge and observed sediment concentrations. Results show that annually on average $34 \mathrm{t} / \mathrm{ha} / \mathrm{year}$ of sediment is removed from the gauged part of the Lake Tana watersheds. Depending on the up-scaling method from the gauged to the ungauged part, 21 to $32 \mathrm{t} /$ ha/year (equivalent to 24-38 Mt/year) is transported from the upland watersheds of which $46 \%$ to $65 \%$ is retained in the flood plains and $93 \%$ to $96 \%$ is trapped on the flood plains and in the lake. Thus, only $4-7 \%$ of all sediment produced in the watersheds leaves the Lake Tana Basin.
\end{abstract}

Keywords: Erosion; Saturation excess; Hydrology; Discharge; Flood plain; Ethiopia; East Africa; Horn of Africa.

\section{INTRODUCTION}

Soil erosion is a serious global environmental problem (Lieskovský and Kenderessy, 2014). The consequences of land degradation and the associated nutrient depletion of soil resources have profound economic implications for low-income countries (Erkossa et al., 2015; Yitbarek et al., 2012). In addition, the increased sediment load is reducing the storage of the reservoirs faster. Moreover, increased turbidity due to sediment reduces light penetration and threatens the aquatic ecosystem; in the case of Lake Tana, the livelihood of over 500,000 people are directly or indirectly dependent on the lake and wetlands (Vijverberg et al., 2009).

Soil erosion by water is a particularly critical problem in the high-rainfall Ethiopian highlands. Although in the semi-arid northern Ethiopian highlands, sediment dynamics and gully formation have been well documented (Aerts et al., 2006; Descheemaeker et al., 2006; Frankl et al., 2011; Frankl et al., 2013; Gebrermichael et al., 2005; Gebreegziabher et al., 2009; Girmay et al., 2009; Haregeweyn et al., 2013), in the humid highlands, sediment dynamics have been less well studied. The main information available consists of data gathered in the Soil Conservation Research Program (SCRP) watersheds. For these relatively small watersheds, Guzman et al. (2013) reported soil loss rates of $5.2 \mathrm{t} / \mathrm{ha} / \mathrm{yr}$ in the $4.8 \mathrm{~km}^{2}$ Andit Tid watershed, 24.7 $\mathrm{t} / \mathrm{ha} / \mathrm{yr}$ in the $1.1 \mathrm{~km}^{2}$ Anjeni watershed, and $7.4 \mathrm{t} / \mathrm{ha} / \mathrm{yr}$ in the $1.1 \mathrm{~km}^{2}$ Maybar watershed. Greater soil loss ranges are report- ed on test plots with 32 to $36 \mathrm{t} / \mathrm{ha} / \mathrm{yr}$ for the Maybar watershed, 87 to $212 \mathrm{t} / \mathrm{ha} / \mathrm{yr}$ for the Andit Tid watershed, and 131 to 170 $\mathrm{t} / \mathrm{ha} / \mathrm{yr}$ for Anjeni watershed (Haile et al., 2006a). Sediment loss as high as $540 \mathrm{t} / \mathrm{ha} / \mathrm{yr}$ has been reported in a small watershed mainly due to gully erosion (Tebebu et al., 2010). Sediment data from the sampling station on the Blue Nile at the border with Sudan indicated that current losses in the $180,000 \mathrm{~km}^{2}$ basin are in the order of $7 \mathrm{t} / \mathrm{ha} / \mathrm{yr}$ (Yasir et al., 2014). Thus, most of the sediment that erodes from the land is deposited on its way to Sudan.

Watershed management requires accurate discharge and sediment predictions. SWAT is often employed to simulate the discharge in the Ethiopian highlands (Betrie et al., 2011; Easton et al., 2010; Setegn et al., 2008, 2009, 2010a, 2010b, 2011; Yasir et al., 2014). Easton et al. (2010) and White et al. (2011) modified SWAT to include saturation excess runoff, which is the major runoff mechanism in the highlands. However, one of the major problems in applying SWAT in any form is the scarcity of data input for validation. For that reason, water balance approaches that are based on available data have been utilized with some success (Conway, 2000; Kebede et al., 2006; Mishra and Singh, 2004; Rientjes et al., 2011; Steenhuis et al., 2009; Tilahun et al., 2015).

Early erosion predictions (Haile et al., 2006b; Haregeweyn and Yohannes, 2003; Tamene et al., 2006) in Ethiopia were either based on the sediment rating curve or the Universal Soil Loss Equation (USLE). More recently, sediment flows have 
been simulated in the Blue Nile basin employing various models: SWAT, in which sediment predictions are based on Modified Universal Soil Loss Equation (MUSLE) (Betrie et al., 2011; Easton et al., 2010; Setegn et al., 2010b; Yasir et al., 2014), the modified SWAT-WB Water Balance model (Easton et al., 2010), Parameter efficient model (PED), that is based on the Hairsine and Rose model (Hairsine and Rose, 1992; Steenhuis et al., 2009), WATEM/SEDEM (Haregeweyn et al., 2013), and the Water Erosion Prediction Project (WEPP) model (Zeleke, 2000).

The studies of Easton et al. (2010) and Setegn et al. (2010b) simulated sediment loads at the gauging stations near Lake Tana. Setegn et al. (2010b) showed that sediment loads of 30 to $60 \mathrm{t} / \mathrm{ha} / \mathrm{yr}$ are exported from the Lake Tana watersheds whereas Easton et al. (2010) predicted that a maximum of $84 \mathrm{t} / \mathrm{ha} / \mathrm{yr}$ can be exported from the Gumara watershed. Recently, Erkossa et al. (2015) estimated unrealistically low sediment yield of less than $5 \mathrm{t} / \mathrm{ha} / \mathrm{yr}$.

Kaba et al. (2014) determined the sediment contribution from the Gumara watershed for a 10-year period using MODIS satellite Imagery. These lake concentrations were an order of magnitude less than the concentrations measured in the rivers at the stream gauges. Some studies estimated sediment inflow to the lake by assuming average sediment load (SMEC 2008) and using empirical equations (Lieskovský and Kenderessy, 2014). The only estimate on sediment accumulated in the lake using measurement is by Ayana et al. (2015) who analyzed two Lake Tana bathymetric surveys (1987 and 2006) and found that $200 \mathrm{Mm}^{3}$ of sediment had settled at the bottom of the lake during this 20-year period.

The above studies and other studies in developing countries have been severely hampered by the lack of reliable long-term records of sediment concentrations (Walling, 2008). For example, simulated sediment loads for the Gumara by Easton et al. (2010) were calibrated with two data points, while Setegn et al. (2010b) used the sediment rating curve by the Ministry of Water Resources and Energy. These rating curves severely under predicted the loads (Moges et al., 2016). According to Walling (2008), to improve sediment load predictions, greater effort should be focused on assembling available datasets. As Walling notes, this either involves seeking out new sources of data or collating and processing the basic data to provide estimates of sediment flux. In addition, standard data analyzing procedures employed in the data rich developed countries cannot be directly used and adopted in developing countries such as Ethiopia where data are limited and quality is affected by politically unstable conditions.

Due to the limitations of existing procedures in estimating sediment budgets in developing countries, this study is concerned with developing a method for recreating realistic suspended sediment fluxes. The objective of this study is, therefore, to develop procedures to reconstruct the long-term suspended sediment concentrations for quantifying sediment budgets when observational data are limited. The study is carried out in the Lake Tana basin where occasional suspended sediment data are available that were collected for generating sediment rating curves for the four major rivers.

\section{MATERIAL AND METHODS}

Study area: the Lake Tana basin

The $3000 \mathrm{~km}^{2}$ Lake Tana is located in the headwaters of the Blue Nile at an elevation of $1,785 \mathrm{~m}$. It is the largest lake in Ethiopia with a drainage area of approximately $15,000 \mathrm{~km}^{2}$. It is the home to a unique fish population of which 20 fish species are endemic (Vijverberg et al., 2009).

In the 1920s, the lake was described as beautiful, pristine with a sandy bottom near the inlets of the major rivers (Cheesman, 1936). While river sediment loads have been decreasing generally worldwide (Wang et al., 2015), sediment concentrations in the Blue Nile and Lake Tana are still increasing (Abate et al., 2015). Currently, the lake water is polluted with sediment and nutrients. The sandy bottoms near the inlets have been replaced by muddy bottoms and deltas which, in the case of the Gilgel Abay River, is $10 \mathrm{~km}$ long.

The lake is fed by four major partly gauged rivers: Gilgel Abay in the south, Megech in the north, and Gumara and Rib in the east (Fig. 1). The Blue Nile exits the lake at the south end where the Chara Chara Weir was constructed in 1995 to regulate the water flow for hydropower generation. The major rivers have special morphological characteristics. For example, the Rib riverbed rose more than $1.5 \mathrm{~m}$ from 1990 to 2002 (SMEC, 2008) at the gauging station. Thus, the flow carrying capacity of the river is reduced. The river overflows its banks regularly during monsoon rain phase and discharge measurements are not conducted when the riverbank floods. Recent LANDSAT 8 images showed a change in flow path at the eastern flank of the lake. In the dry monsoon phase, the riverbed is dug out for sand mining. The holes created fill up with sediment during the rain phase.

Analysis of a 90-m resolution digital elevation model (DEM) shows the slope in the Lake Tana Basin ranges from 0 to 55 degrees (Table 1). Altitude of the basin varies from $1785 \mathrm{~m}$ to $4094 \mathrm{~m}$ with a mean elevation of $2418 \mathrm{~m}$ (Table 1 ). Most of the basin consists of cropland on the moderate sloping hillsides and grass in the valley bottoms (Table 1). Soils vary

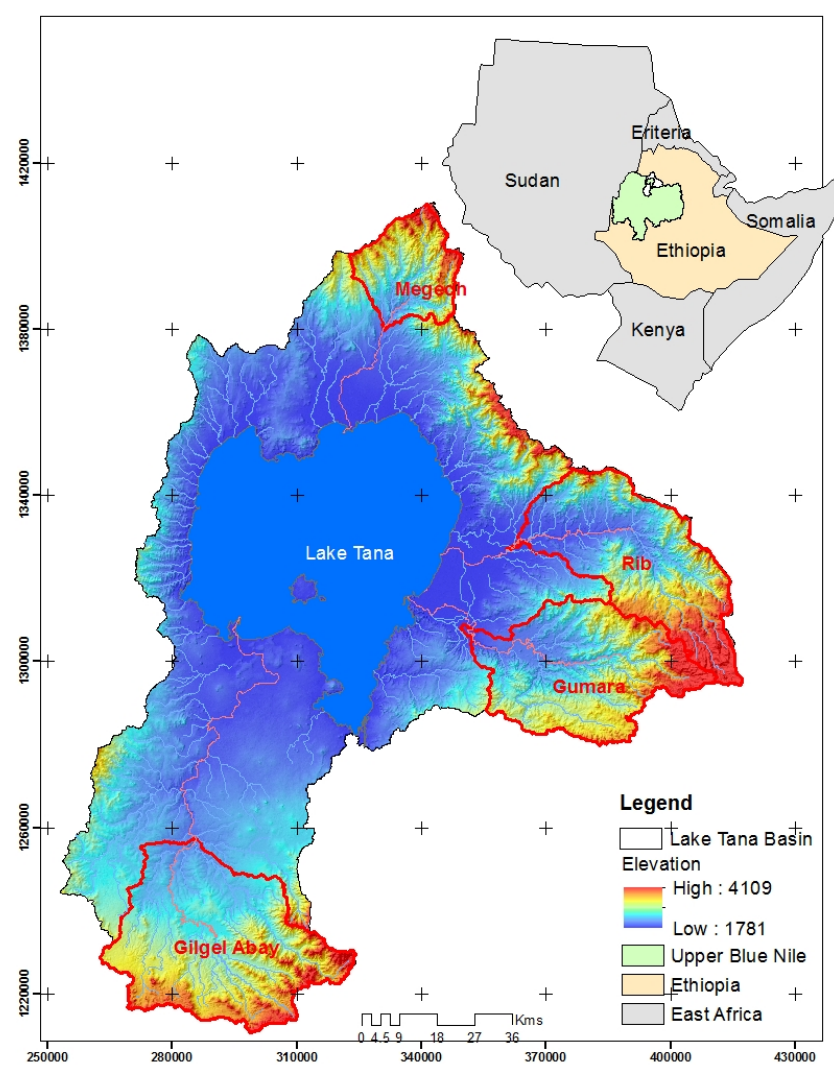

Fig. 1. The Lake Tana basin with the four major watersheds: Gilgel Abay, Gumara, Rib and Megech. 
Table 1. Physiographic characteristics of the four gauged basins in percent of area: Gilgel (GA), Gumara (Gum), Rib and Megech (Meg) and ungauged parts of Lake Tana watersheds.

\begin{tabular}{|c|c|c|c|c|c|c|c|c|c|}
\hline \multirow{2}{*}{ Slope (\%) } & \multicolumn{4}{|c|}{ Gauged } & \multirow{2}{*}{$\begin{array}{c}\text { Whole watershed } \\
\text { Ungauged }\end{array}$} & \multicolumn{4}{|c|}{ Ungauged parts of each watershed } \\
\hline & GA & Gum & Rib & Meg & & GA & Gum & Rib & Meg \\
\hline $0-2$ & 22 & 7 & 7 & 1 & 29 & 33.4 & 50.1 & 35.4 & 40.7 \\
\hline $2-8$ & 50 & 25 & 30 & 17 & 42 & 51.5 & 28.8 & 21.0 & 46.6 \\
\hline $8-16$ & 19 & 31 & 25 & 26 & 15 & 10.6 & 13.5 & 16.8 & 9.8 \\
\hline $16-30$ & 9 & 28 & 22 & 32 & 8 & 3.6 & 6.2 & 15.4 & 2.3 \\
\hline$>30$ & 1 & 9 & 16 & 25 & 5 & 0.9 & 1.4 & 11.5 & 0.6 \\
\hline \multicolumn{10}{|l|}{ Land use (\%) } \\
\hline Cultivated & 74 & 64 & 64 & 95 & 60 & 69.2 & 63.5 & 63.4 & 99.1 \\
\hline Partly Cultivated & 26 & 32 & 26 & 3 & 30 & 20.4 & 32.7 & 6.0 & 0.9 \\
\hline Forest & 0 & 0 & 0 & 0 & 0.2 & 0.0 & 0.0 & 0.0 & 0.0 \\
\hline Grassland & 0 & 4 & 9 & 0.5 & 3.5 & 0.1 & 0.0 & 21.2 & 0.0 \\
\hline Water & 0 & 0 & 0 & 0 & 0.2 & 0.0 & 0.0 & 0.0 & 0.0 \\
\hline Swamp & 0 & 0 & 0 & 0 & 0.3 & 0.0 & 2.6 & 0.0 & 0.0 \\
\hline Plantation & 0 & 0 & 0.1 & 0 & 0.1 & 0.0 & 1.1 & 0.3 & 0.0 \\
\hline Shrub land & 0 & 0 & 0 & 0 & 6 & 10.3 & 0.0 & 9.0 & 0.0 \\
\hline Urban & $<1$ & $<1$ & $<1$ & 1.2 & $<1$ & 0.1 & 0.0 & 0.1 & 0.0 \\
\hline Woodland & 0 & 0 & 0 & 0 & $<1$ & 0.0 & 0.0 & 0.0 & 0.0 \\
\hline Afro Alpine & 0 & 0.4 & 0 & 0 & 0 & 0.0 & 0.0 & 0.0 & 0.0 \\
\hline \multicolumn{10}{|l|}{ Soil (\%) } \\
\hline Haplic Alisols & 41 & 0 & 0 & 0 & 1 & 3.1 & 0.0 & 0.0 & 0.0 \\
\hline Haplic Luvisols & 56 & 63 & 0 & 0 & 19 & 40.9 & 15.7 & 0.0 & 0.0 \\
\hline Haplic Nitosols & $<1$ & 0 & 0 & 9 & 2 & 3.7 & 0.0 & 1.3 & 0.0 \\
\hline Eutric Regosols & $<1$ & 0 & 0 & 0 & $<1$ & 0.9 & 0.0 & 0.0 & 0.0 \\
\hline Euric Vertisols & 2 & 3 & 0 & 4 & 23 & 14.1 & 23.1 & 9.5 & 74.2 \\
\hline Euric Fluvisols & 0 & $<1$ & 24 & 0 & 16 & 1.8 & 41.9 & 42.0 & 2.7 \\
\hline Eutric Leptosols & 0 & 9 & 36 & 82 & 18 & 0.1 & 3.5 & 46.9 & 4.1 \\
\hline Chromic Luvisols & 0 & 24 & 40 & 5 & 21 & 22.6 & 15.6 & 0.3 & 19.1 \\
\hline Urban & 0 & $<1$ & $<1$ & $<1$ & $<1$ & 0.0 & 0.0 & 0.0 & 0.0 \\
\hline Lithic Leptosols & 0 & 0 & 0 & 0 & 0 & 12.9 & 0.0 & 0.0 & 0.0 \\
\hline
\end{tabular}

from Haplic Luvisols and Alisols in the Gilgel Abay, Luvisols in the Gumara, and Eutric Leptosols and Chromic Luvisols in the Rib and Megech (Table 1).

The climate in the Lake Tana basin is affected by the movement of the inter-tropical convergence zone which results in a single rainy season between June and September and a dry period the rest of the year. The average dry season (NovemberApril) rainfall is $117 \mathrm{~mm}$ and potential evaporation is $710 \mathrm{~mm}$. The wet season (May-October) rainfall is $1400 \mathrm{~mm}$ and potential evaporation is $645 \mathrm{~mm}$ for data used in the calibration and validation periods. More than $90 \%$ of the annual rainfall occurs in the wet monsoon phase. The mean annual temperature in the basin is $23^{\circ} \mathrm{C}$ in the relatively lower lying areas such as Bahir Dar and ranges between $15-20^{\circ} \mathrm{C}$ in the middle and high altitudes.

\section{Model input and validation data Meteorological data}

Rainfall and temperature data were obtained from the Ethiopian National Meteorological Agency (ENMA) and were checked for erroneous input data. Missing and erroneous data were estimated using mean values of same dates in all years with data. Thiessen polygon method was applied on data obtained from the surrounding meteorological stations to determine the areal rainfall data for each watershed. The potential evapotranspiration was calculated from minimum and maximum air temperatures and other climate variables using the FAO Penman method with data from the Bahir Dar, Gonder and Dangila weather stations (Allen et al., 1998).

\section{Discharge}

Daily stream discharge of the Gilgel Abay, Gumara, Rib, and Megech rivers were obtained from the Ministry of Water, Irrigation and Electricity of Ethiopia (MoWIE). Discharge was measured by recording the stage, cross-section of the channel and flow velocity at the gauging stations. Flow records from 1994 to 2009 were used for calibration and validation. Missing flow data were replaced with the mean of the available discharge data for the specific day. One of the limitations of the MoWIE discharge data is that the stage discharge curves are infrequently updated (Abate et al., 2015) and as we will discuss later, this introduces errors which will become obvious when we compare model outputs with observed values of the Rib River discharge.

\section{Suspended sediment concentrations}

Suspended sediment concentrations were determined by the Ministry of Water, Irrigation and Electricity (MWIE) at the gauging stations at times when stage discharge relationships were developed by collecting water samples with plastic bottles of known volume. Elevated sediment concentrations were observed during the rainy phase in June, July, and August. Daily sediment concentrations were determined dividing the daily sediment load by the discharge measured during the same day. MWIE sediment load data were available between 1964 and 2009. The distribution of the suspended sediment measurements is uneven; some months are without any data, mainly during the dry monsoon phase when sediment concentrations 
are low. The Gumara and the Rib Rivers were monitored most intensively with just over 60 data pairs of sediment load and discharge. Sediment concentration of all rivers, apart from the Gilgel Abay, peaks before the discharge. This general trend of sediment concentrations is similar to the small experimental watersheds - Andit Tid, Maybar and Anjeni (Guzman et al., 2013). According to Guzman et al. (2013) and Zegeye et al. (2010), the greatest concentrations occur at the time when the rills are formed in the newly plowed agricultural lands. From August to October when Lake Tana is filled up, most sediment is lost at the outlet. The data on sediment concentration were insufficient to have separate calibration and validation periods.

\section{Model selection}

Since the sediment concentration measurements are limited, simulation of sediment contribution from the watersheds requires understanding the local hydrology and the underlying hydrological processes (Steenhuis et al., 2009). The models discussed before (such as SWAT, WEPP etc.) were developed for temperate climates. In the temperate cold winter, the solar radiation and potential evaporation are minimum. Rainfall is distributed evenly throughout the year; it rains more than the potential evaporation during the dormant winter period (Lyon et al., 2005). Most of the runoff occurs during spring. In monsoon climates, the solar radiation and potential evaporation are approximately constant year-round. Rainfall is concentrated in three-to-four month periods and exceeds the potential evaporation (Liu et al., 2008). Soils stay dry until the beginning of the growing season and gradually become wetter; surface runoff and interflow increase as the rain progresses. During the rainy phase in the (sub) humid areas, there is more rainfall than can be evaporated or stored in the soil.

The PED model is a conceptual rainfall runoff and sediment loss model with minimum calibration parameters based on the saturation excess runoff process. It has been applied to catchments ranging from a few square kilometers (e.g. Anjeni (1.1 $\mathrm{km}^{2}$, Tilahun et al, 2013a), Andit Tid (4.8 km², Engda, 2011), Enkulal (4 km², Tilahun et al., 2013a) and Debre Mawi $\left(0.95 \mathrm{~km}^{2}\right.$, Tilahun et al., $2013 \mathrm{~b}$; Tilahun et al., 2015$\left.)\right)$ to hundreds of thousands of square kilometers (e.g. Blue Nile, $180,000 \mathrm{~km}^{2}$ ) and showed good performance (Steenhuis et al., 2009; Tilahun et al., 2013a; Tilahun et al., 2015). Comparing the predictions with other models used in the humid Blue Nile basin, PED performs as well or better. Hence, the PED model is applied in this study to avoid over parameterization and ensure process interpretability.

\section{Description of the PED model}

The PED model represents the local hydrological and erosion processes. It classifies the watershed into two runoff producing areas (periodically saturated areas and degraded hill slopes) and one recharge area (permeable hill slopes) that release the excess precipitation, the base flow and interflow. The two runoff producing areas are assumed to be sources of sediment while the base flow may pick up sediment at low concentrations from the banks. The hydrology model inputs are limited to precipitation, potential evapotranspiration, and nine landscape parameters. The sediment model uses the discharges predicted by the hydrology model and maximum six parameters for the erodibility of the soil at the beginning and end of the rainy phase for each of the three areas.

\section{PED's hydrology module}

The hydrology module is a water balance model that divides the watershed into periodically saturated areas, degraded hill slopes and permeable hill slopes. The discharge $Q$ at the outlet is written as

$$
Q=A_{1} Q_{1}+A_{2} Q_{2}+A_{3}\left(Q_{B}+Q_{I}\right)
$$

where $Q_{1}$ and $Q_{2}$ are saturation excess runoff from saturated and degraded areas $\left(\mathrm{mm} \mathrm{d}^{-1}\right), Q_{B}$ and $Q_{I}$ are base flow and interflow $\left(\mathrm{mm} \mathrm{d}^{-1}\right), A_{1}, A_{2}$ and $A_{3}$ are area fractions of the saturated, degraded areas and the recharge hillside area, respectively. Area fraction $A_{1}$ are the periodically saturated areas that consist of the relatively flatter parts of the landscape, usually in the valley bottoms. After the areas become saturated during the rain phase, they generate surface runoff. Area fraction $A_{2}$ represents the degraded areas that have a thin layer of soil over a sublayer with restrictive water movement that needs minimum rainfall to fill up to saturation and generate runoff. These areas are located at different places in the landscape. Area $A_{3}$ is the recharge areas located on the hillslope that are of sufficient depth and transmissivity to transport excess rainwater via interflow or base flow to the valley bottoms

Surface runoff is simulated as any rainfall in excess of soil saturation

$$
Q_{1,2}=\frac{S_{t-\Delta t}-S_{\max }+(P-P E T) \Delta t}{\Delta t}
$$

where $P$ is precipitation $\left(\mathrm{mm} \mathrm{d}^{-1}\right), P E T$ is potential evapotranspiration $\left(\mathrm{mm} \mathrm{d}^{-1}\right), \mathrm{S}_{t-\Delta t}$ is previous time step storage $(\mathrm{mm}), \Delta t$ is the time step (d), and $S_{\max }$ is the maximum water storage capacity in the rootzone.

The storage, $S_{t}$, in each of the three regions is calculated with the Thornthwaite-Mather procedure (Steenhuis and Van der Molen, 1986; Thornthwaite and Mather, 1955)

$$
\begin{aligned}
& S_{t}=S_{t-\Delta t}+(P-P E T) \Delta t \quad \text { when } P \geq P E T \\
& S_{t}=S_{t-\Delta t}\left[\exp \left(\frac{(P-P E T) \Delta t}{S_{\max }}\right)\right] \quad \text { when } P<P E T
\end{aligned}
$$

Base flow, $Q_{B}$, is calculated as a first order reservoir and interflow, $Q_{I}$, as a zero-order reservoir (Steenhuis et al., 2009). The groundwater storage and the recharge to the interflow compartment calculations depend on whether the groundwater storage has reached its maximum value of $B S_{\max }$. Recharge to the interflow compartment only occurs when the base flow reservoir is full. The storage in the base flow aquifer is calculated when the groundwater storage is less than the maximum (i.e., $B S_{t}<B S_{\max }$ ):

$$
\begin{aligned}
& S_{t}=B S_{t-\Delta \mathrm{t}}+\left(P_{e r c}-Q_{B}\right) \Delta t . \\
& P_{e r c, I}=0
\end{aligned}
$$

where $P_{e r c}$ is the total groundwater recharge from the root zone $\left(\mathrm{mm} \mathrm{d}^{-1}\right)$ and $P_{\text {erc }, I}$ is the recharge to the interflow compartment $\left(\mathrm{mm} \mathrm{d}^{-1}\right)$. When the groundwater exceeds the maximum storage (i.e., $B S_{t-\Delta t}+\left(P_{e r c}-Q_{B}\right) \Delta \mathrm{t}>B S_{\max }$ ): 


$$
B S_{t}=B S_{\max }
$$

$P_{e r c, I}=B S_{t-\Delta t}+\left(P_{e r c}-Q_{B}\right) \Delta \mathrm{t}-B S_{\max }$

The base flow, $Q_{B}$, and interflow, $Q_{I}$, are then obtained as:

$Q_{B}=B S_{t} \frac{[1-\exp (-\alpha \Delta t)]}{\Delta t} \quad$ when $B S_{t}>B S_{\max }$

$Q_{I}=\sum_{\tau=1}^{\tau^{*}}\left(2^{*} \mathrm{P}_{\mathrm{erc}, \mathrm{I}}\left(\tau^{*}-\tau\right)\left(\frac{1}{\tau^{*}}-\frac{\tau}{\tau^{* 2}}\right), \tau \leq \tau^{*}\right.$

where $\alpha=0.69 / t_{1 / 2}$ and where $t_{1 / 2}$ is time taken in days to reduce volume of the base flow reservoir by half under no recharge conditions; $\tau$ is the day after the rainstorm and $P_{e r c, I}$ is the amount of the percolate that reached the interflow storage and is calculated as the recharge in excess of what can be stored in the base flow reservoir, and $\tau^{*}$ is the duration of interflow after any rainstorm.

\section{PED's Sediment module}

In the sediment model, the two runoff source areas are considered the main sources of sediment. Unlike in the Tilahun et al. ( 2013a) model application, in our model formulation the subsurface flow contains some sediment in the rainy phase (Fox and Wilson, 2010; Fox et al., 2007; Tebebu et al., 2010).

The concentration of sediment, $C(\mathrm{~g} / \mathrm{l})$, in the river is obtained by dividing the sediment yield by the total watershed predicted discharge from the hydrological model.

$$
\begin{aligned}
& C= \\
& \frac{A_{1} Q_{1}^{1.4}\left[a_{s, 1}+H\left(a_{t, 1}-a_{s, 1}\right)\right]+A_{2} Q_{2}^{1.4}\left[a_{s, 2}+H\left(a_{t, 2}-a_{s, 2}\right)\right]+a_{t, 3} Q_{3}^{1.4}}{A_{1} Q_{1}+A_{2} Q_{2}+A_{3} Q_{3}}
\end{aligned}
$$

where the subscript numbers refer to the three areas introduced with Eq. 1, $Q$ is the runoff ( $\mathrm{mm} /$ day) calculated with the hydrology model, i.e., $Q_{1}$, $Q_{2}$ are calculated with Eq. 2 , and $Q_{3}$ is the sum of $Q_{B}$ in Eq. 6 and $Q_{I}$ in Eq. 7. $H$ is the fraction of the contributing runoff area with active rill formation (Fig. 2) that occurs after plowing and is determined by field observations and is a constant relating the flux to the sediment concentration for each of the three areas with the subscript $t$ for transport limited and subscript $s$ for source limited. Note that unlike in Tilahun et al. (2013a), the base flow is not free of sediment in the large river system, especially in the beginning of the rainy phase when the sediment is dry and easily picked up.

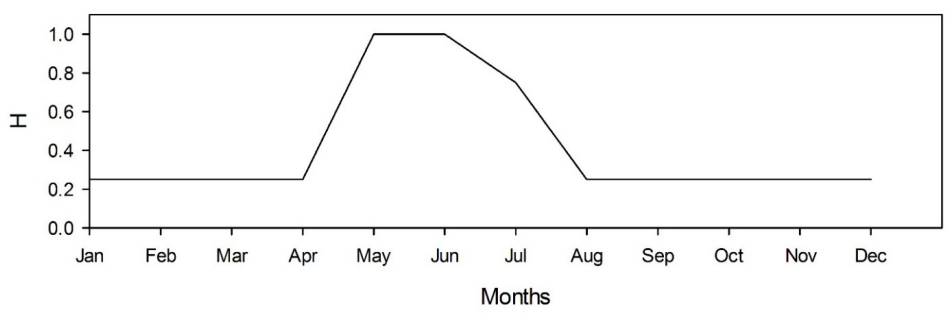

Fig. 2. Fraction of transport capacity, $\mathrm{H}$, available for moving sediment. During plowing in May and the beginning of June sediment concentrations are at the transport capacity limit $(\mathrm{H}=1)$ after which $\mathrm{H}$ is decreasing when less sediment is available for pickup.
Measured sediment concentration is required to calibrate parameters, $\mathrm{a}_{\mathrm{t}}$, the sediment transport limiting factor, and $\mathrm{a}_{\mathrm{s}}$, sediment source limiting factor, which are functions of the slope, Manning's roughness coefficient, slope length, effective deposition and vegetation cover ( $\mathrm{Yu}$ et al., 1997). The observed data were obtained from MoWIE which measured both the concentration and the discharge as part of obtaining a rating curve. When, in the calibration period the predicted discharge did not match the observed discharge, we used the previous day's rainfall for the day of observation because of a time lag of runoff reaching the gauge.

\section{Sediment budget}

The flood plains found near the lake (Fig.1) act as flood storage (Dessie et al., 2014). During storage, sediment settles on the land and the flood plains are the sinks for sediment. SMEC (2008) found that an area of $350-450 \mathrm{~km}^{2}$ is inundated around Lake Tana during floods. This inundated flood plain area is approximately $6 \%$ of the ungauged part (or $4 \%$ of the whole watershed).

For the purpose of the sediment budget, the flood plain includes the deltas that have been formed at the mouth of the river in the lake. Assuming, as discussed above, that the flood plain and the lake are sediment sinks and the remaining parts of the watershed are sediment sources, the sediment budget for the flood plain can then be written as:

$$
S_{\text {flplane }}=M_{\text {gauged }}+M_{\text {ungauged }}-S_{\text {lake }}-M_{\text {blNile }}
$$

where $S_{\text {flplane }}$ is the amount of sediment stored in the flood plain, $M_{\text {gauged }}$ is the annual sediment loss from the gauged part of the basin, $M_{\text {ungauged }}$ is the sediment loss from the ungauged part of the basin, $S_{\text {lake }}$ is the annual amount of sediment stored in the lake, and $M_{\text {blNile }}$ is the sediment lost annually at the outlet of the lake in the Blue Nile (all in Mt/year). Consequently, the difference between the incoming sediment from the watershed and that leaving the lake is deposited in the lake and in the flood plains.

\section{Model calibration, validation, and setup}

All the model parameters were calibrated on a daily basis from 1994-1999 and validated for 2000-2009. The parameters are first determined by maximizing the efficiency criterion of the Nash-Sutcliffe efficiency coefficient (NSE), then the coefficient of determination $\left(\mathrm{R}^{2}\right)$, and finally minimizing the Root Mean Square Error (RMSE) and percent bias (Pbias). For calibration of parameters of the hydrology model, we started by giving initial values of three physical area model parameters $A_{1}, A_{2}$ and $A_{3}$ and the maximum storage process parameters, $S_{\max }$, of the three areas and sub-surface parameters $\left(B S_{\max }, \tau *\right.$ and $\left.t_{1 / 2}\right)$. The initial values were based on the previous model runs of Steenhuis et al. (2009) and Tilahun et al. (2013a). These initial values were changed systematically until the best goodness-offit was achieved between simulated and observed flows. Previous sensitivity analysis has shown that the relative areas, aquifer half-life, and the duration of the interflow after a rainstorm are the most sensitive parameters 
(Tilahun et al., 2013). The maximum storage, $S_{\max }$, especially can be changed over a wide range before it affects the outflow predictions.

Daily sediment concentrations were computed by calculating daily sediment load first and then dividing the daily load by the total daily discharge. In the sediment model, there are two calibration parameters $a_{t}$ and $a_{s}$ for each of the two surface runoff source areas, $A_{1}$ and $A_{2}$, and for the interflow and base flow, $A_{3}$, that represents the sediment that is being picked up in the river channel during low flows. The model is calibrated in the period of 1994-2009. These constants are tweaked to yield a best fit between measured and simulated daily sediment concentrations.

\section{RESULTS AND DISCUSSION \\ Hydrology}

Evaluation of the hydrology module

The model parameters listed in Table 2 show a reasonable agreement (Table 3) for all four basins except for the portion of the hillside, $A_{3}$, in which the water infiltrates and supplies interflow and base flow. The area is smaller for Megech and Rib than for Gilgel Abay and Gumara.

Gilgel Abay: Using a runoff contributing area of $15 \%(5 \%$ saturated and $10 \%$ degraded), an aquifer half-life of 45 days and a 40-day interflow period (Table 2), the predicted and observed daily discharge for the Gilgel Abay shows good agreement for the calibration period from 1994-1999 (hydrograph in Fig. 3A and scatter plot $3 \mathrm{C}, \mathrm{NSE}=0.77$, Table 3 ). The fluctuations during the high-flow periods in some of the years were not captured due in part to non-representative rainfall amounts and the sparse rain gauge network (Dessie et al., 2014), and the anomaly in the collected data in the fall of 1996.
During the validation period (2000-2009), the rising and falling limbs, and most of the peaks, were reasonably estimated (Fig. $3 \mathrm{~B}$; NSE $=0.71$, Table 3). The Pbias values of 2.62 (Table 3) for calibration also indicated that the model performed well (Pbias value for flow \pm 25 is acceptable, Moriasi et al., 2007) but slightly underestimated the flow initially during the calibration period and then minimally overestimated later at the end of the calibration period. The base flow after 2006, that increased unexpectedly compared to the previous years, was underestimated suggesting a change in channel configuration that was not reflected in the rating curve, as discussed later.

Table 2. PED parameter values for the hydrology simulations for four major rivers in the Lake Tana Basin.

\begin{tabular}{|l|l|l|l|l|l|}
\hline Parameters & Units & G_Abay & Gumara & Rib & Megech \\
\hline Area $A_{1}$ & $\%$ & 0.05 & 0.05 & 0.05 & 0.05 \\
\hline$S_{\max }$ in $A_{1}$ & $\mathrm{~mm}$ & 65 & 90 & 100 & 100 \\
\hline Area $A_{2}$ & $\%$ & 0.1 & 0.12 & 0.1 & 0.1 \\
\hline$S_{\max }$ in $A_{2}$ & $\mathrm{~mm}$ & 35 & 40 & 30 & 30 \\
\hline Area $A_{3}$ & $\%$ & 0.85 & 0.83 & 0.45 & 0.5 \\
\hline$S_{\max }$ in $A_{3}$ & $\mathrm{~mm}$ & 125 & 100 & 135 & 250 \\
\hline$B S_{\max }$ & $\mathrm{mm}$ & 70 & 75 & 75 & 80 \\
\hline$t_{1 / 2}$ & Days & 45 & 50 & 20 & 30 \\
\hline$\tau^{*}$ & Days & 40 & 40 & 25 & 20 \\
\hline
\end{tabular}

$A_{1}, A_{2}$ and $A_{3}$ are area fractions of the saturated, degraded and recharge hillside areas respectively. $S_{\max }$ is the maximum water storage capacity; $B S_{\max }$ is maximum base flow storage of linear reservoir; $t_{1 / 2}$ is time taken in days to reduce volume of the base flow reservoir by half under no recharge conditions; $\tau^{*}$ is the duration of the period after a single rainstorm (until interflow ceases).

Table 3. PED model efficiency criteria for calibration and validation of discharge for the four major rivers in the Tana Basin. Units are $\mathrm{mm} \mathrm{d}^{-1}$ for the daily values and $\mathrm{mm} \mathrm{month}{ }^{-1}$ for monthly values.

\begin{tabular}{|c|c|c|c|c|c|c|}
\hline \multirow[b]{2}{*}{ Watersheds } & \multirow{2}{*}{\multicolumn{2}{|c|}{ Description }} & \multicolumn{2}{|c|}{ Calibration } & \multicolumn{2}{|c|}{ Validation } \\
\hline & & & Daily & Monthly & Daily & Monthly \\
\hline \multirow{7}{*}{ 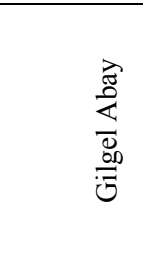 } & \multirow{2}{*}{ Mean } & Predicted & 2.9 & 87.1 & 3.0 & 92.0 \\
\hline & & Observed & 2.8 & 89.5 & 2.8 & 84.9 \\
\hline & & $\mathrm{R}^{2}$ & 0.77 & 0.91 & 0.75 & 0.94 \\
\hline & & NSE & 0.77 & 0.91 & 0.71 & 0.87 \\
\hline & & RMSE & 1.85 & 32.01 & 1.91 & 35.01 \\
\hline & & RVE & -0.01 & 0.03 & -0.09 & -0.09 \\
\hline & & Pbias & 2.62 & -8.42 & 2.61 & -8.42 \\
\hline \multirow{7}{*}{ 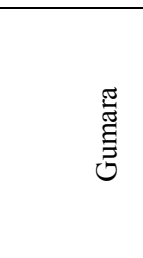 } & \multirow{2}{*}{ Mean } & Predicted & 2.45 & $74 . .73$ & 2.22 & 66.82 \\
\hline & & Observed & 2.58 & 78.61 & 2.55 & 77.49 \\
\hline & & $\mathrm{R}^{2}$ & 0.72 & 0.87 & 0.78 & 0.92 \\
\hline & & NSE & 0.70 & 0.86 & 0.77 & 0.90 \\
\hline & & RMSE & 2.12 & 40.33 & 1.99 & 36.27 \\
\hline & & RVE & 0.04 & 0.05 & 0.14 & 0.14 \\
\hline & & Pbias & 4.93 & 13.77 & 4.93 & 6.49 \\
\hline \multirow{7}{*}{$\vec{z}$} & \multirow[b]{2}{*}{ Mean } & Predicted & 1.05 & 31.83 & 1.00 & 30.52 \\
\hline & & Observed & 1.06 & 32.77 & 1.04 & 31.75 \\
\hline & & $\mathrm{R}^{2}$ & 0.72 & 0.91 & 0.64 & 0.84 \\
\hline & & NSE & 0.71 & 0.90 & 0.55 & 0.81 \\
\hline & & RMSE & 1.02 & 15.75 & 1.12 & 19.84 \\
\hline & & RVE & 0.01 & 0.03 & -0.03 & -0.03 \\
\hline & & Pbias & 2.88 & 2.88 & 3.89 & 1.53 \\
\hline \multirow{7}{*}{$\begin{array}{l}\overline{\tilde{J}} \\
\mathbb{S}_{0} \\
\stackrel{\infty}{\Sigma}\end{array}$} & \multirow{2}{*}{ Mean } & Predicted & 12 & 34.5 & 13.2 & 30.2 \\
\hline & & Observed & 11.5 & 36 & 10.1 & 39.8 \\
\hline & \multirow{5}{*}{ 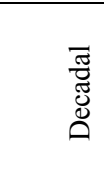 } & $\mathrm{R}^{2}$ & 0.85 & 0.91 & 0.79 & 0.84 \\
\hline & & NSE & 0.71 & 0.76 & 0.31 & 0.66 \\
\hline & & RMSE & 11.4 & 24 & 13.1 & 34.1 \\
\hline & & RVE & 0.04 & -0.04 & 0.24 & -0.32 \\
\hline & & Pbias & -4.4 & -4.4 & -31.3 & -31.8 \\
\hline
\end{tabular}



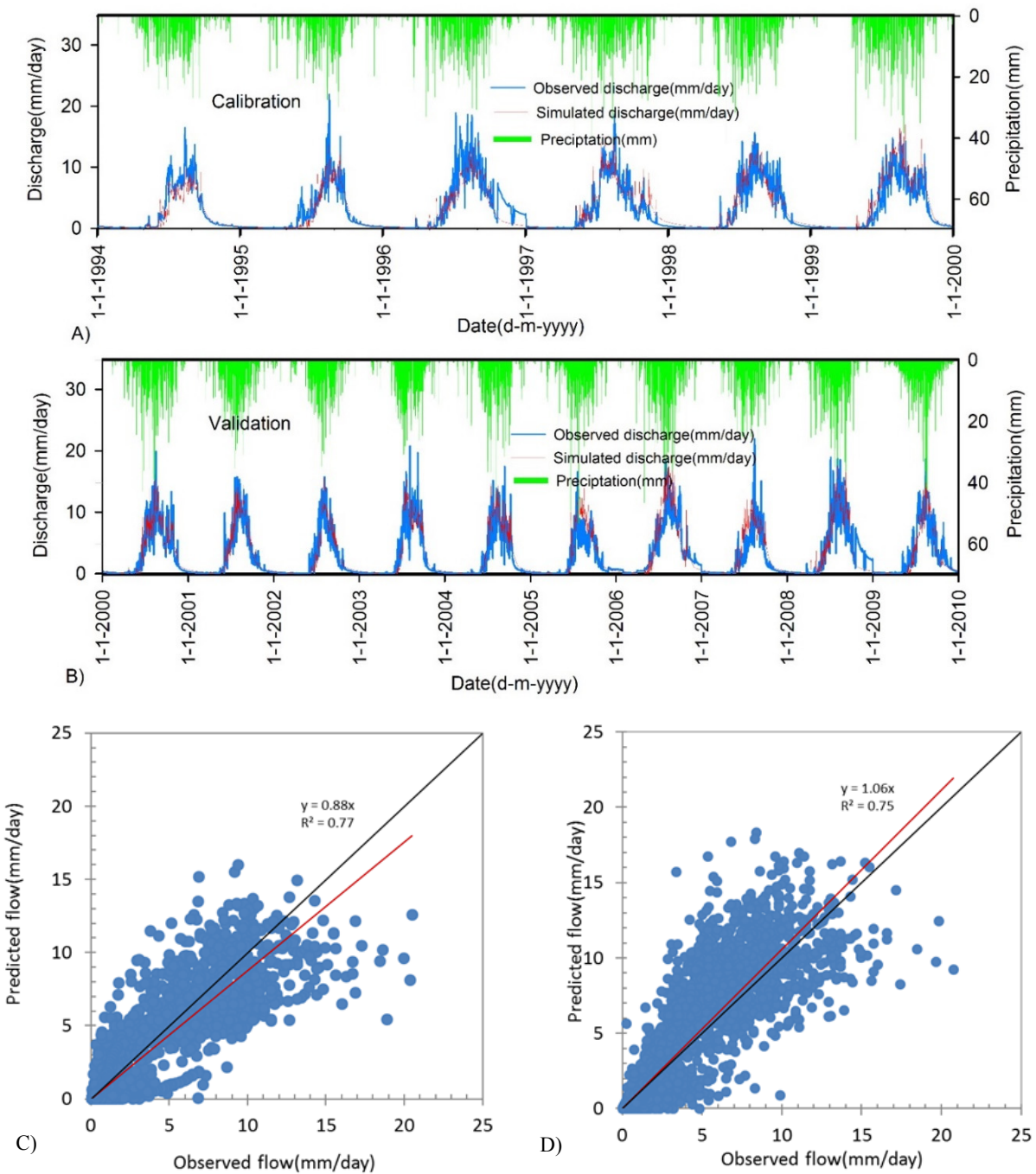

Fig. 3. Simulated and observed stream flows in mm/d for Gilgel Abay River A) Calibration (1994-1999), B) Validation(2000-2009), C) Scatter plot of simulated vs observed for calibration, D) Scatter plot of simulated vs observed validation.

Gumara: With nearly the same parameter set as for the Gilgel Abay model (Table 2), the model generally predicted discharge well. The NSE values for daily flows were 0.70 for calibration and 0.77 for the validation period (Fig. 4, Table 3). A smaller number of missing precipitation data during validation likely was related to better model performance.

Rib: Although the surface runoff parameters for areas $A_{1}$ and $A_{2}$ used in the model for the Rib are similar to both the Gumara and the Gilgel Abay, the subsurface parameters are much different (Table 2). The area contributing to the stream flow, the half-life and duration of the interflow period are all significantly less than for the Gumara and Gilgel Abay (Table 2). The daily flows were predicted reasonably well for the calibration period with NSE values for daily discharges of 0.71 (Table 3). The daily NSE decreased to 0.55 in the calibration period (Table 3). Especially in the validation period, the peak values were over predicted because the observed discharges were limited to bank full discharges equivalent to $6 \mathrm{~mm} /$ day as is discussed below. During the period of September to January in both 1996 and 1997, base flow was elevated similar to what was observed in the Gilgel Abay (Fig. 5A).

Megech: The Megech River has a reservoir upstream and flow is attenuated. Therefore, the flow is summarized in 10 days to avoid the effect of the reservoir. The $\mathrm{R}^{2}$ is 0.85 and 0.79 and NSE is 0.71 and 0.31 for calibration and validation, respectively, on a 10-day basis (Table 3, Fig. 6). The latter is caused by an unexpected and unlikely reduction in observed discharge starting in 2006. A possible reason may be withdrawal of water for irrigation purposes upstream of the gauging station beginning in 2006.

\section{Discussion of discharge predictions}

It is remarkable that the surface flow parameters for all four watersheds are nearly the same especially if we take the relative insensitivity of the $S_{\max }$ value in determining the simulated discharge into account. These values are also similar compared with other watersheds where we used PED (Tilahun et al., 2013b). Moreover, it is curious that starting with the same year (2006), the observed discharge values were less for the predicted base flow of the Gilgel Abay and all of the discharge of the Megech (Figs. 3 and 5). The excessive amounts of rainfall during that year affecting the riverbed without recalibration of the rating curve is likely the explanation for the apparent change in reported discharges (SMEC, 2008).

The fractional areas for Gilgel Abay and Gumara add up to 1 but Rib and Megech are only 0.6 and 0.65 (Table 2). A fractural area proportion of 1 means that the calculated inter flow, base flow and storm flow are equal to the long-term discharge measured at the outlet. In other words, since the long-term average of the discharge in the PED model equals the average of net 

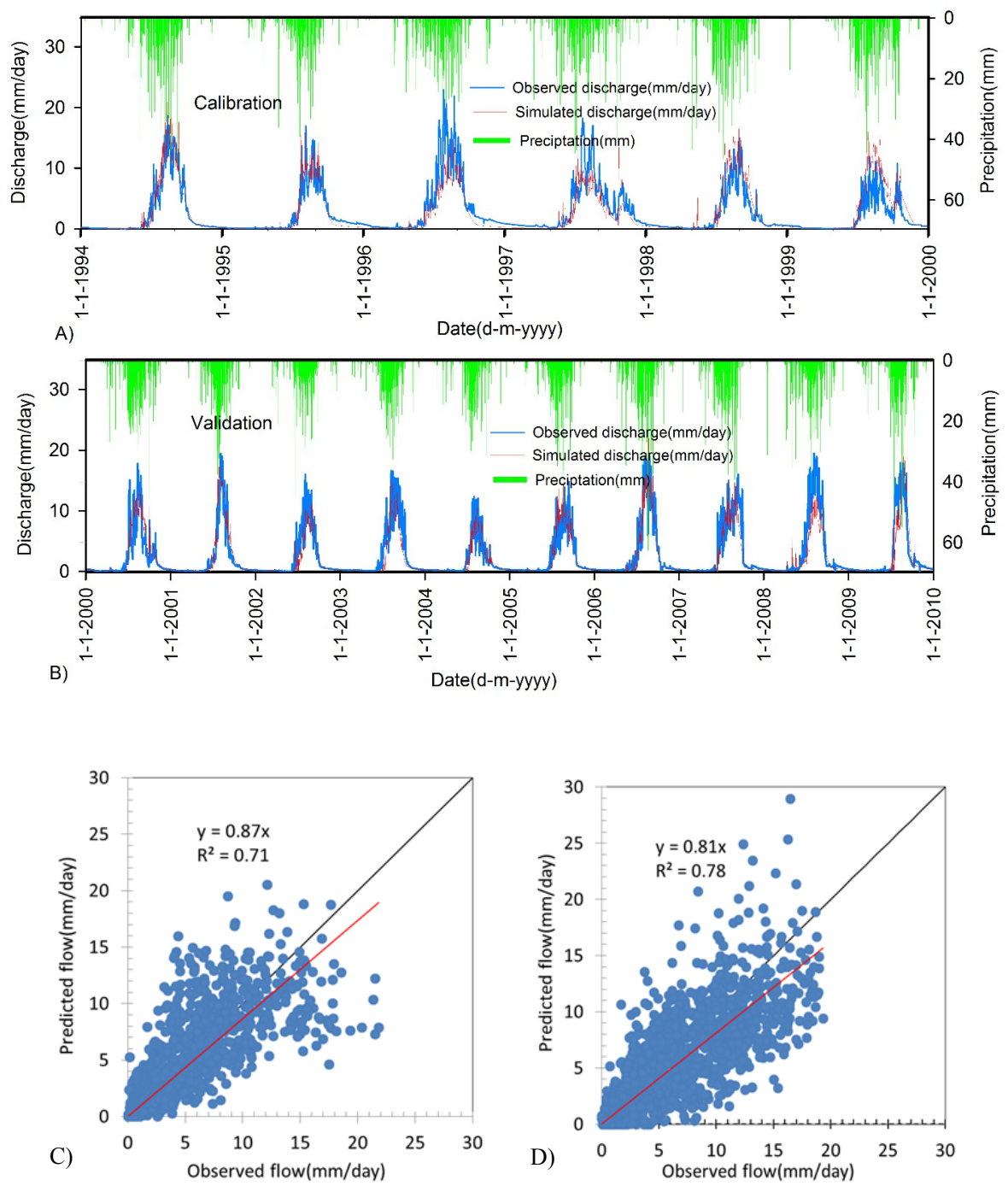

Fig. 4. Simulated and observed stream flows in mm/d for Gumara River A) Calibration (1994-1999), B) Validation(2000-2009), C) Scatter plot of simulated vs observed for calibration, D) Scatter plot of simulated vs observed validation.

precipitation (i.e., rainfall minus evaporation), all precipitation reaches the outlet eventually. However, the total contributing areas of 0.6 for Rib and 0.65 for Megech means that the net input precipitation is much more than the discharge at the outlet. Thus, the unaccounted net precipitation either flows via the subsurface under the gauge to the lake or the discharge is not measured correctly.

The under prediction of the high flows for the Rib River is a consequence of the increased riverbed levels (SMEC, 2008) and can be observed clearly in Fig. 5A and in Dessie et al. (2014). In Fig. 5A, the under prediction is indicated with ellipses 1 and 2 in which the measured flows do not exceed an equivalent of $6 \mathrm{~mm} /$ day with predicted flows much greater than that. The under prediction of the high flows at the Rib stream gauge is even more clear in Dessie et al. (2014) where in the period from July 10 to September 15, 2012, a newly installed upstream gauge on the Rib shows the weekly peak flows were up to $300 \mathrm{~m}^{3} / \mathrm{sec}$ (equivalent of $22 \mathrm{~mm} /$ day) but in the downstream gauge, the peak flows were invariably at $150 \mathrm{~m}^{3} / \mathrm{sec}$ (equivalent to $10 \mathrm{~mm} /$ day). Since rivers are extremely flashy, the peak runoff occurs only part of the day and the $6 \mathrm{~mm} /$ day observed over the whole day (this paper) is comparable with the $10 \mathrm{~mm} /$ day over part of the day (Dessie et al., 2014). The final cause for the "missing" rainfall (i.e., contributing areas not adding up to 1) is that the Rib watershed is underlain by permeable tuffs (Dessie et al., 2014) facilitating subsurface flows and this decreases the amount of the discharge at the gauge. Large springs have been observed downstream of the gauge. Some of the "missing" rainwater is resurfacing in these springs.

Under prediction of the flow by the Megech River (Fig. 6) is either due to the Angereb Dam or, since the area is volcanic, subsurface flow through faults and pipes (and not measured by the gauge) could occur as well. The over prediction of the base flow after 2006 is likely caused by a change in the riverbed as discussed above.

\section{Sediment \\ Evaluation of the sediment module}

The sediment concentrations were measured by the Ministry of Water, Irrigation and Electricity (MoWIE) as part of determining the sediment rating curves for each of the four rivers in the Lake Tana basin. As expected, the measured high sediment concentrations (Fig. 7) occurred during large flow events In addition, for similar runoff events, the concentrations were greater during the onset of the rainfall phase than later in the rain-phase. 

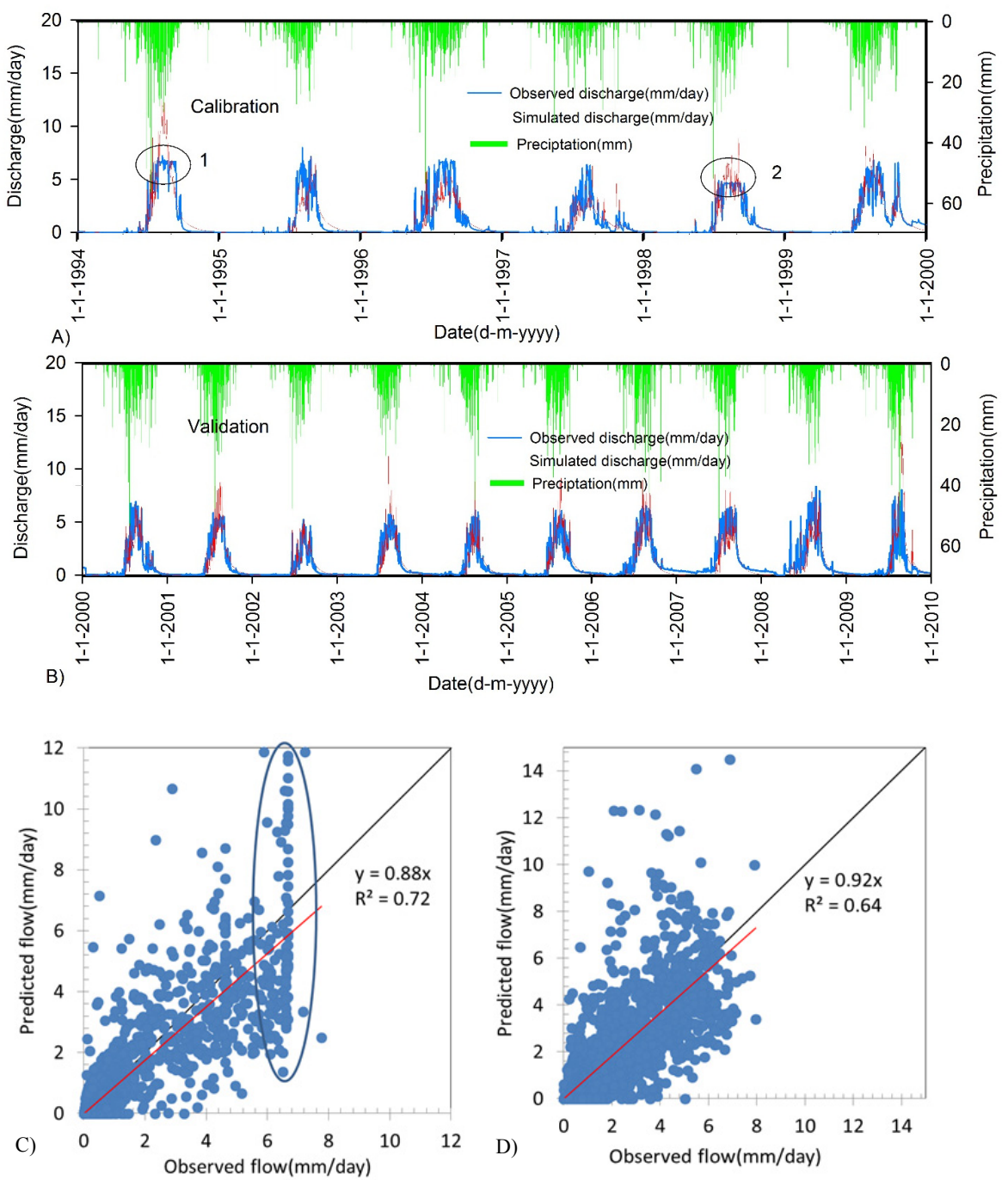

Fig. 5. Simulated and observed stream flows in mm/d for Rib River. A) Calibration (1994-1999), B) Validation (2000-2009), C) Scatter plot of simulated vs observed for calibration, D) Scatter plot of simulated vs observed validation.

The concentration measurements were employed to calibrate the " $a$ " parameters (Eq. 8) in the sediment module. The surface runoff for the 16 years, originating from the saturated and degraded area and the subsurface flow (interflow and base flow) that are required for the sediment module, were predicted with the PED hydrology module. The trend of decreasing sediment concentration is captured by the $\mathrm{H}$ function (Eq. 8) with cumulative rainfall (Fig. 2).

The predicted and observed sediment concentrations as a function of time for the major rivers are shown in Fig. 8 with the input parameter listed in Table 4. Daily observed versus corresponding predicted sediment concentrations for the four watersheds agree well as shown in Table 5 with Nash Sutcliff values ranging from 0.5 to 0.84 .

The average sediment loads from these watersheds (19942009) were $35( \pm 1.96)( \pm \mathrm{SE}) \mathrm{t} / \mathrm{ha} / \mathrm{yr}$ for the Gilgel Abay, 49 $( \pm 2.51)( \pm \mathrm{SE}) \mathrm{t} / \mathrm{ha} / \mathrm{yr}$ for the Gumara, $25( \pm 1.85)( \pm \mathrm{SE}) \mathrm{t} / \mathrm{ha} / \mathrm{yr}$ for the Rib, and $12( \pm 0.73)( \pm$ SE) t/ha/yr for the Megech (Table 6). The sediment loss per unit area in the Gumara is $49 \mathrm{t} / \mathrm{ha}$ and is greater than any other river. However, the Gilgel Abay, with 14.3 Mt/yr, transports most sediment in the lake because runoff losses are much greater than any other watershed. For reducing the sediment load to the lake, upland management practices should be concentrated in the Gilgel Abay basin but also the Gumara basin which has the greatest soil loss per ha.
Table 4. PED model input parameters for sediment concentration simulations for the transport limit, $\mathrm{a}_{\mathrm{t}}$ and the source limit, $\mathrm{a}_{\mathrm{s}}$ in $\left(\left(\mathrm{g} \mathrm{l}^{-1}\right)\left(\mathrm{mm} \mathrm{d}^{-1}\right)^{0.4}\right)$ for the four main rivers in the Lake Tana basin.

\begin{tabular}{|c|c|c|c|c|c|c|c|c|}
\hline Source & \multicolumn{2}{|c|}{ G_Abay } & \multicolumn{2}{c|}{ Gumara } & \multicolumn{2}{c|}{ Rib } & \multicolumn{2}{c|}{ Megech } \\
\hline & $\mathrm{a}_{\mathrm{t}}$ & $\mathrm{a}_{\mathrm{s}}$ & $\mathrm{a}_{\mathrm{t}}$ & $\mathrm{a}_{\mathrm{s}}$ & $\mathrm{a}_{\mathrm{t}}$ & $\mathrm{a}_{\mathrm{s}}$ & $\mathrm{a}_{\mathrm{t}}$ & $\mathrm{a}_{\mathrm{s}}$ \\
\hline Saturated & 3.0 & 2.5 & 7.0 & 4.0 & 8.0 & 5.0 & 2.5 & 1.5 \\
\hline Degraded & 5.0 & 5.0 & 15 & 5.0 & 10 & 5.0 & 4.5 & 2.2 \\
\hline River bank & 0.7 & 0 & 0.8 & 0 & 0.6 & 0 & 0.15 & 0 \\
\hline
\end{tabular}

Table 5. PED model efficiency criteria for simulated vs observed sediment concentrations for the four major rivers in the Lake Tana basin.

\begin{tabular}{|r|r|c|c|c|c|}
\hline \multicolumn{2}{|c|}{$1994-2009$} & \multicolumn{4}{|c|}{ Daily sediment concentration (g/l) } \\
\cline { 3 - 6 } \multicolumn{2}{|c|}{} & $\begin{array}{c}\text { Gilgel } \\
\text { Abay }\end{array}$ & Gumara & Rib & Megech \\
\hline \multirow{3}{\tilde{E}}{} & predicted & 1.8 & 3.3 & 4.8 & 0.77 \\
\cline { 2 - 6 } & observed & 1.6 & 3.2 & 4.6 & 0.79 \\
\hline \multirow{4}{*}{} & $\mathrm{R}^{2}$ & 0.60 & 0.56 & 0.7 & 0.84 \\
\cline { 2 - 6 } & $\mathrm{NSE}$ & 0.50 & 0.67 & 0.73 & 0.84 \\
\cline { 2 - 6 } & RMSE(g/l) & 0.72 & 1.25 & 1.71 & 0.32 \\
\cline { 2 - 6 } & Error & -0.18 & -0.08 & -0.16 & 0.02 \\
\hline
\end{tabular}


Table 6. Sediment budget for gauged and ungauged portions of the four Lake Tana watersheds: Gilgel Abay, Gumara, Rib, Megech.

\begin{tabular}{|c|c|c|c|c|c|c|c|}
\hline \multirow[b]{2}{*}{ 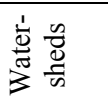 } & \multicolumn{3}{|c|}{ Gauged } & \multicolumn{3}{|c|}{ Ungauged } & \multirow{2}{*}{$\begin{array}{c}\text { Total four rivers } \\
\mathrm{Mt} / \mathrm{yr}\end{array}$} \\
\hline & $\begin{array}{l}\text { Area } \\
\left(\mathrm{km}^{2}\right)\end{array}$ & Total Mt/year $^{1}$ & $\begin{array}{c}\text { Unit area } \\
\mathrm{t} / \mathrm{ha} / \mathrm{yr}\end{array}$ & $\begin{array}{l}\text { Area } \\
\left(\mathrm{km}^{2}\right)\end{array}$ & Total Mt/yr & $\begin{array}{c}\text { Unit area } \\
\text { t/ha/yr }\end{array}$ & \\
\hline Megech & 500 & 0.6 & 12.2 & 163 & 0.3 & 21 & 0.9 \\
\hline Gumara & 1281 & 6.3 & 49.4 & 688 & 1.9 & 28 & 8.2 \\
\hline Rib & 1289 & 3.2 & 24.6 & 379 & 0.7 & 17.7 & 3.9 \\
\hline G_Abay & 1665 & 5.9 & 35.4 & 2362 & 8.4 & 35.4 & 14.3 \\
\hline Total & 4735 & 16 & & 3592 & 11.3 & & 27.3 \\
\hline Average & & & 33.8 & & & 31.5 & 32.8 \\
\hline
\end{tabular}

${ }^{1} 10^{12}$ grams or 1 million tons
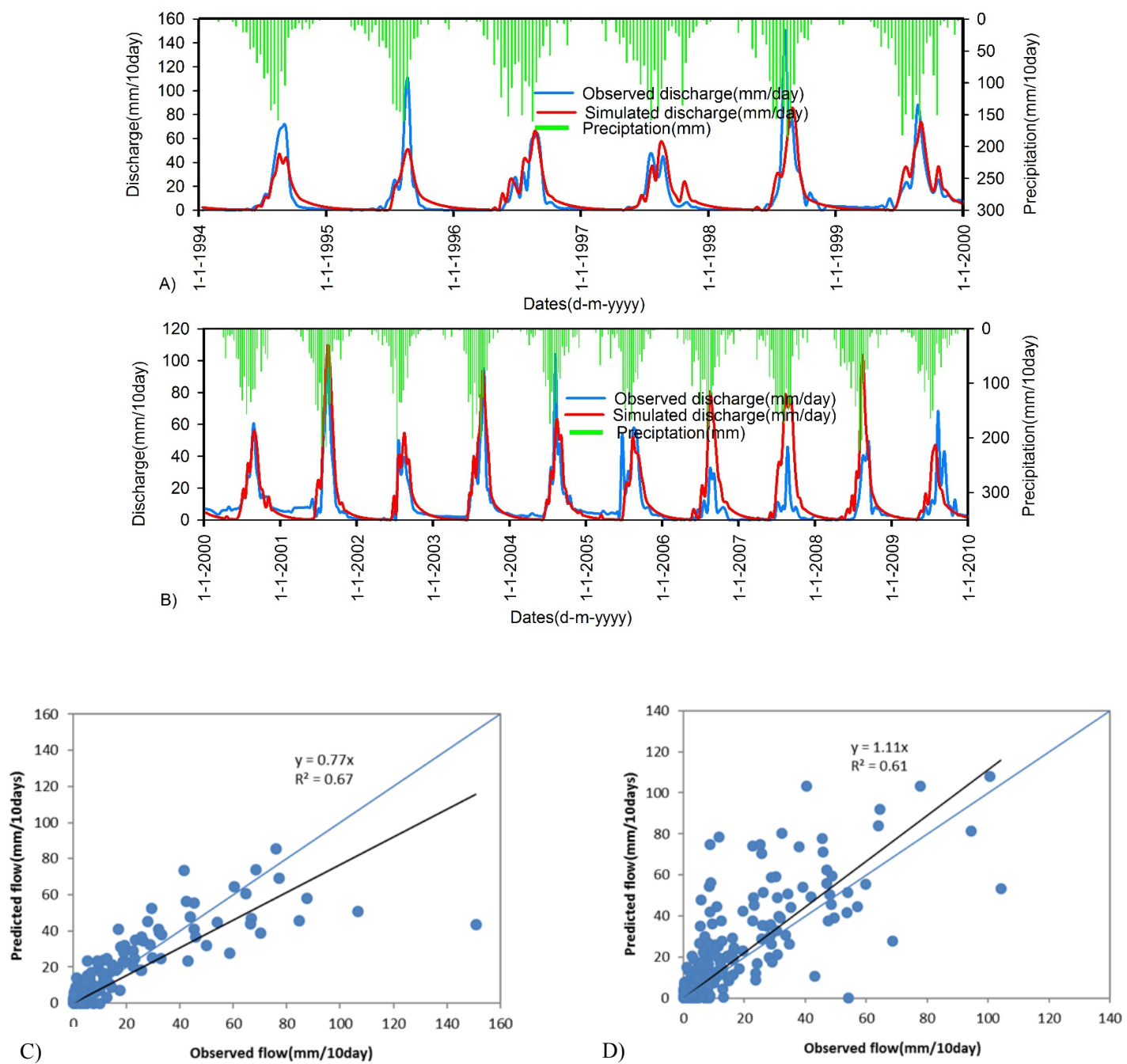

Fig. 6. Simulated and observed stream flows in mm/10 days for Megech River. A) Calibration (1994-1999), B) Validation (2000-2009), C) Scatter plot of simulated vs observed for calibration, D) Scatter plot of simulated vs observed validation.

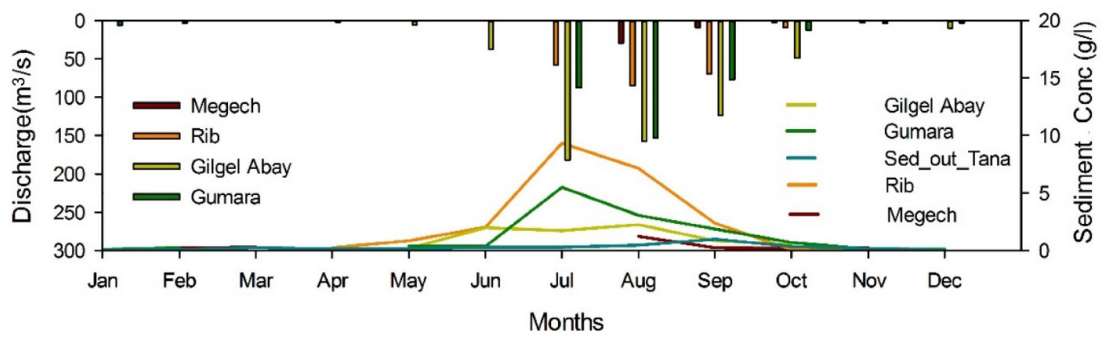

Fig. 7. Average monthly sediment concentration (lines) and discharge (bars) of the four major rivers in the Tana Basin for the years 1964-2009. 
a)
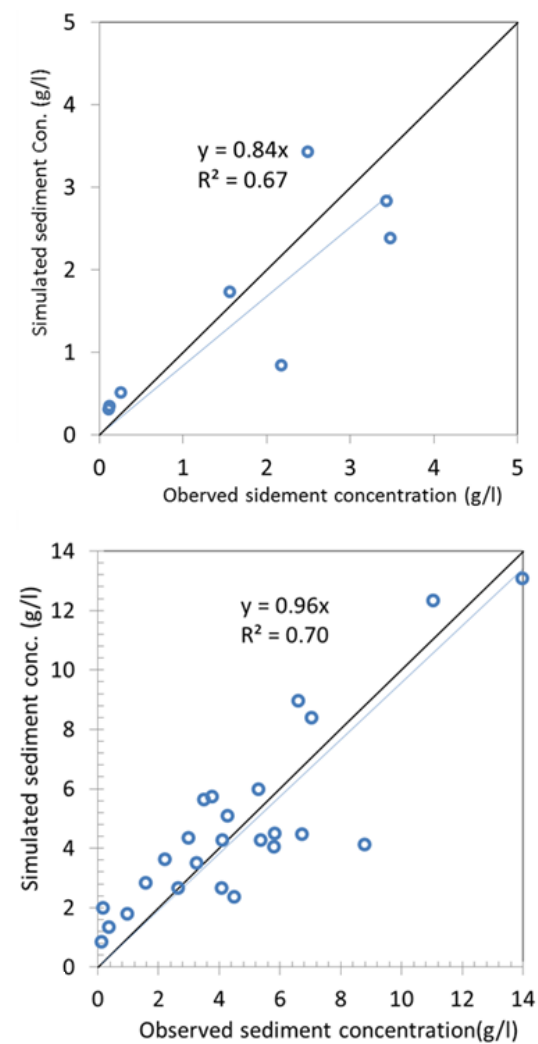

b)
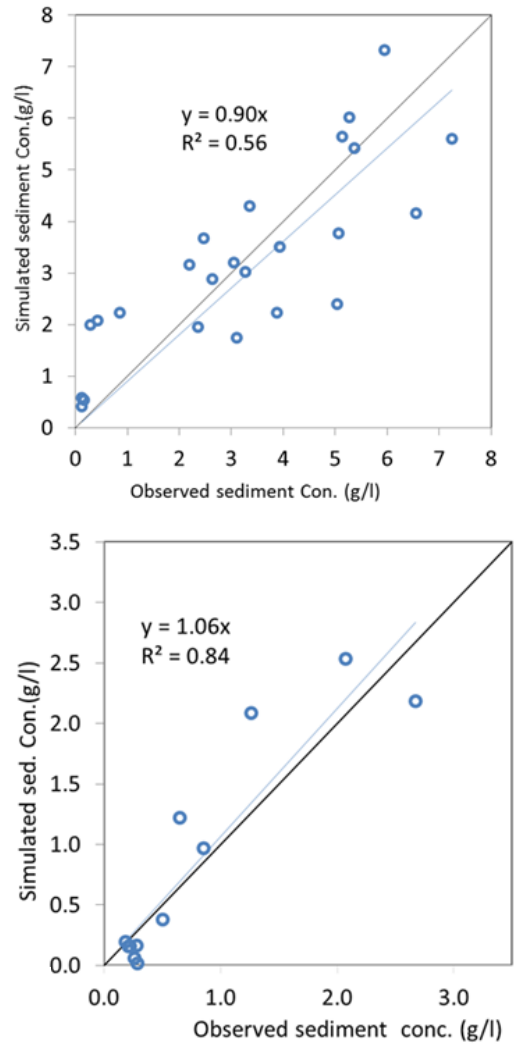

Fig. 8. Simulated vs Observed sediment concentration for a) Gilgel Abay, b) Gumara, c) Rib and d) Megech.

The concentration in the water when the rill is formed is related to the maximum amount of sediments that can be carried by the water in the rill (Tebebu et al., 2010; Zegeye et al., 2010) and is represented in the $a_{t}$ coefficient in the model. Its magnitude is related to the stream power which is a function of the slope of the land (Gao, 2008). Since the slopes in the Gilgel Abay watershed are relatively flatter than the Rib and Gumara (Table 1), the transport capacity for the Gilgel Abay in Table 4 is less than for the Rib and the Gumara. The Megech has a reservoir upstream of the sampling location that takes out most of the sediment and can explain the low transport coefficient despite the steep terrain (Table 4).

Once the rill network is formed, it is reasonable that sediment concentration decreases and at the end of the rainfall monsoon phase, the concentration is source limited and depends on the cohesion of the soil and on the soil type. This is represented by the source limit term as in the model. The soils in the Gumara and Rib have a greater percentage of chromic Luvisols (loamy sand, Table 1) and thus easier to erode than the more clay-like soils in the Gilgel Abay and Megech. Therefore, the $a_{t}$ and $a_{s}$ values in Table 4 are less for the Gilgel Abay and the Megech than for the Gumara and Rib.

\section{Sediment contributions to Lake Tana}

Table 6 shows the amount of sediment for the four rivers of the gauged part of the basin (1994-2009) which is equal to 16 $\mathrm{Mt} / \mathrm{yr}$ (Mt is equal to $10^{6} \mathrm{t}$ ). In Table 7 , the sediment budget is detailed for Lake Tana and the flood plains. Based on an analysis by Ayana et al. (2015), who compared the bathymetric surveys of Lake Tana in 1987 and 2006, the sediment amount settled at the bottom of the lake was found to be $200 \mathrm{Mm}^{3}$. The annual sediment load deposited in the lake, $S_{\text {lake, }}$ (Eq. 9) can be calculated from this estimate, assuming a bulk density of 1,200 $\mathrm{kg} / \mathrm{m}^{3}$, deducting an average organic matter accumulation in the lake, and assuming the organic matter content of the sediment at the bottom of the lake as 3.4\% (Vanmaercke et al., 2010). Based on this, we calculated that the sediment accumulation was 11.6 Mt/yr (Table 7).

The 1.6 Mt/yr of sediment leaving the lake in the Blue Nile (Table 7) was found by multiplying the monthly average of the available measured concentrations at the outlet (Fig. 7) by the monthly average discharge. The sediment delivered to the lake is the sum of what is settled at the lake bottom plus that which has left the lake and equals 13.2 Mt/yr (Table 7).

As can be seen from Table 1, the topographic characteristics of the Gilgel Abay is nearly the same as the ungauged part of the basin. Thus, a reasonable estimate for the upper bound of the soil loss for the ungauged part of the four major rivers in the Lake Tana basin can be obtained by using the sediment parameters of Gilgel Abay assuming that the hydrological parameters and the rainfall remains the same as for the gauged part of the particular watershed. The results of these calculations are given in Table 6. We find that the total loss from the ungauged parts of the four rivers is $11.3 \mathrm{Mt} / \mathrm{yr}$, or an average soil loss of $31.5 \mathrm{t} / \mathrm{ha} / \mathrm{yr}$ (Table 6).

There are additional areas in the Lake Tana basin that are not part of the four large watersheds. We will assume that these areas have the same soil loss as the average soil loss per ha of the ungauged watersheds, which are $31.5 \mathrm{t} / \mathrm{ha} / \mathrm{yr}$. Thus, by multiplying the total area of ungauged basin (minus the flood plains) with the average soil loss of $31.5 \mathrm{t} / \mathrm{ha}$, the upper bound for sediment contribution of all the ungauged parts of the basin outside the flood plain is $21.5 \mathrm{Mt} / \mathrm{yr}$ (Table 7). The lower bound is estimated by taking the $12.2 \mathrm{t} / \mathrm{ha} / \mathrm{yr}$ soil loss in the Megech, which is the lowest of the four major gauged rivers, and use this for the entire ungauged part of the basin. This comes to $8.3 \mathrm{Mt} / \mathrm{yr}$ from the total ungauged basin, without including the flood plain (Table 7). 
Table 7. Sediment budget for the Lake Tana consisting of predicted minimum and maximum contribution from the watershed and the measured sediments deposited in the lake and that leaving the Lake at the outlet. The minimum contribution assumes that the ungauged part of the Lake Tana watershed contributes at least equal to the sediment contribution of Megech (the smallest) and the maximum contribution assumes that the ungauged part has similar landscape characteristics as the Gilgel Abay.

\begin{tabular}{|c|c|c|c|c|c|}
\hline \multirow[t]{2}{*}{ Description } & \multirow[t]{2}{*}{ Area $\left(\mathrm{km}^{2}\right)$} & \multicolumn{2}{|c|}{ Lower bound } & \multicolumn{2}{|c|}{ Upper bound } \\
\hline & & $\mathrm{t} / \mathrm{ha} / \mathrm{yr}$ & $\mathrm{Mt} / \mathrm{yr}$ & $\mathrm{t} / \mathrm{ha} / \mathrm{yr}$ & $\mathrm{Mt} / \mathrm{yr}$ \\
\hline \multicolumn{6}{|l|}{ Watershed contribution } \\
\hline $\begin{array}{l}\text { Gauged river contributions "Mgauged" as in } \\
\text { Eq. (9) (predicted, Table 6) }\end{array}$ & 4735 & 33.8 & 16.0 & 33.8 & 16.0 \\
\hline $\begin{array}{l}\text { Ungauged river contributions minus flood- } \\
\text { plains "Mungauged" as in Eq. (9) (estimated, } \\
\text { Table 6) }\end{array}$ & 6829 & 12.2 & 8.3 & 31.5 & 21.5 \\
\hline $\begin{array}{l}\text { Total watershed contribution minus flood- } \\
\text { plains }\end{array}$ & 11564 & 21.0 & 24.3 & 32.4 & 37.5 \\
\hline \multicolumn{6}{|c|}{ Sediment reaching the flood plain and lake } \\
\hline $\begin{array}{l}\text { Deposited in the lake (measured) "Slake" as } \\
\text { in Eq. (9) }\end{array}$ & \multirow{3}{*}{3000} & 38.7 & 11.6 & 38.7 & 11.6 \\
\hline $\begin{array}{l}\text { Outflow from the lake (measured) "blNile" as } \\
\text { in Eq. (9) }\end{array}$ & & 5.3 & 1.6 & 5.3 & 1.6 \\
\hline Total sediment reaching the lake (measured) & & 44.0 & 13.2 & 44.0 & 13.2 \\
\hline $\begin{array}{l}\text { Retained in floodplains and deltas (calculated) } \\
\text { "Sflplane" as in Eq. (9) }\end{array}$ & 436 & 255 & 11.1 & 558 & 24.3 \\
\hline
\end{tabular}

Table 8. Annual sediment mass balance of Lake Tana and its floodplain.

\begin{tabular}{|l|c|c|c|c|c|c|}
\hline \multirow{2}{*}{ Location } & \multicolumn{3}{|c|}{ Lower bound } & \multicolumn{3}{|c|}{ Upper bound } \\
\cline { 2 - 4 } & \multirow{2}{*}{$\begin{array}{c}\text { Delivered } \\
\text { Mt/year }\end{array}$} & \multicolumn{2}{|c|}{ Retained } & \multirow{2}{*}{$\begin{array}{c}\text { Delivered } \\
\text { Mt/year }\end{array}$} & \multicolumn{2}{|c|}{ Retained } \\
\cline { 3 - 4 } \cline { 6 - 8 } & Mt/year & Portion & & Mear & Portion \\
\hline Floodplain \& delta (Table 7) & 24.3 & 11.1 & 0.46 & 37.5 & 24.3 & 0.65 \\
\hline Lake (Table 7, measured) & 13.2 & 11.6 & 0.88 & 13.2 & 11.6 & 0.88 \\
\hline Floodplain, delta and lake & 24.3 & 22.7 & 0.93 & 37.5 & 35.9 & 0.96 \\
\hline
\end{tabular}

The final sediment budget calculations and the portion of the sediment retained in the flood plain, the lake, and both the flood plain and lake together, are shown in Table 8 for both the lower and upper bounds of the sediment contributed by the ungauged basins. The portion retained can be calculated simply as the sediment retained minus the incoming sediment.

The amount of sediment retained in the flood plain is greatly dependent on the amount of sediment delivered from the gauged and ungauged parts. We find for the lower bound $46 \%$ of the sediment is retained in the flood plain (Table 8). For the upper bound $65 \%$ is retained in the flood plain.

The annual sediment load that comes into the lake is equal to the sediment deposited in the lake (11.6 Mt/year) plus the amount leaving the lake (1.6 Mt/yr). Since these two quantities have been measured, the retention in the lake is independent of predicted amount of sediment originating from the watershed. We find in this way that the amount of sediment retained in the lake equaled $88 \%$. Finally, the sediment from the upland retained in both the flood plain and lake varies between $93 \%$ (lower bound) and 96\% (upper bound, Table 8 ).

The evidence of the near shore deposition is most obvious for the Gilgel Abay (with a relatively small flood plain); it has formed a peninsula of approximately $10 \mathrm{~km}$ long and $2 \mathrm{~km}$ wide. The Gumara and Rib rivers have a large flood plain area and the additional land formed offshore, which is around 0.8 by $3 \mathrm{~km}$, is comparatively smaller (Abate et al., 2015).

In addition, our prediction of the PED model can be compared with a water supply reservoir (Angereb) in the Lake Tana basin that has accumulated $1.8 \mathrm{Mm}^{3}$ of sediment within 11 years (Haregeweyn et al., 2012). The sediment accumulated within the reservoir is $0.2 \mathrm{Mt} / \mathrm{yr}$ for the $68 \mathrm{~km}^{2}$ watershed; this is equivalent to $29 \mathrm{t} / \mathrm{ha} / \mathrm{yr}$. This value is a similar order of magnitude to the sediment delivered by other watersheds in the
Ethiopian highlands (Abate et al., 2017; Dagnew et al., 2015; Tilahun et al., 2013a, 2015; Vanmaercke et al., 2010). Finally, the soil losses reported by Erkossa et al. (2015) and Lemma et al. (2017), with $2.7 \mathrm{t} / \mathrm{ha} / \mathrm{yr}$, are unrealistically low. Based on the average reported sediment concentration of $4.4 \mathrm{~g} / \mathrm{l}$ in Lemma et al. (2017), it can be easily shown that their sediment losses should agree with our calculations of around $30 \mathrm{t} / \mathrm{ha} / \mathrm{yr}$.

\section{Prioritizing upland management practices for Lake Tana}

Finally, our results have implications on prioritizing management practices for reducing the sediment load to Lake Tana. The Gilgel Abay basin receives the most rainfall resulting in the greatest discharge and, of the four basins, the second highest sediment concentration at the outlet. Thus, to reduce sediment losses to the lake, the first priority should be given to installing upland best management practices at the runoff source areas in the Gilgel Abay watershed. A second priority for installing soil and water conservation practices is the Gumara watershed which has the greatest erosional soil loss per ha.

\section{CONCLUSION}

This manuscript presents a method for realistically recreating the long-term suspended sediment concentrations in a developing country watershed where data of this type is extremely scarce. The study was carried out in the Lake Tana basin where the PED model was fitted to the long-term discharge data and the occasional measurements of sediment concentrations in the four major rivers. Average annual sediment loss from the gauged part of the watershed is $33.8 \mathrm{t} / \mathrm{ha}$. Annual accumulation of sediment in Lake Tana was measured at $10 \mathrm{t} / \mathrm{ha}$ when averaged over the watershed area. A small amount of sediment 
flows out of the lake to the Blue Nile River. Bounds of sediment loss for the ungauged basin were established. The upper bound was $31.5 \mathrm{t} / \mathrm{ha}$ and the lower bound was $12.2 \mathrm{t} / \mathrm{ha}$. Based on this, we calculated that the sediment retained in the near shore areas and in the flood plains was between $47 \%$ and $63 \%$ of the sediment generated in the uplands. The sediment coming from the uplands retained by the flood plain and lake was between $94 \%$ and $96 \%$. The portion that entered the lake and that was retained amounted to $88 \%$. With the greatest discharge, second highest sediment concentration, and smallest flood plain, the Gilgel Abay contributes the most sediment to the lake. To reduce soil losses to the lake, upland management practices should be concentrated in the Gilgel Abay basin because it is the greatest sediment contributor to Lake Tana.

Acknowledgements. Funding for this research was obtained from USAID through the research project called "Participatory Enhanced Engagement in Research" or PEER Science project (grant number AID-OAA-A-11-00012). Additional funding was also obtained from Higher Education for Development (HED), United States Department of Agriculture (USDA) and funds provided by Cornell University, partly through the highly-appreciated gift of an anonymous donor. Finally, Peggy Stevens improved our Ethiopian/Dutch English.

\section{REFERENCES}

Abate, M., Nyssen, J, Steenhuis, T.S., Moges, M.M., Tilahun, S.A., Enku, T., Adgo, E., 2015. Morphological changes of Gumara River channel over 50 years, upper Blue Nile basin, Ethiopia. Journal of Hydrology, 525, 152-164.

Abate, M., Nyssen, J., Moges, M.M., Enku, T., Zimale, F.A., Tilahun, S.A., Adgo, E., Steenhuis, T.S., 2017. Long-term landscape changes in the Lake Tana basin as evidenced by delta development and flood plain aggradation, Ethiopia. Land Degradation \& Development, 28, 6, 1820-1830. DOI: 10.1002/ldr.2648.

Aerts, R., Maes, W., November, E., Behailu, M., Poesen, J., Deckers, J., Hermy, M., Muys, B., 2006. Surface runoff and seed trapping efficiency of shrubs in a regenerating semiarid woodland in northern Ethiopia. Catena, 65, 61-70.

Allen, R.G., Pereira, L.S., Raes, D., Smith, M., 1998. Crop evapotranspiration - Guidelines for computing crop water requirements. FAO Irrigation and drainage paper 56. FAO, Rome, 300, 9, D05109.

Ayana, E.K., Philpot, W.D., Melesse, A.M., Steenhuis, T.S., 2015. Assessing the potential of MODIS/Terra version 5 images to improve near shore lake bathymetric surveys. International Journal of Applied Earth Observation and Geoinformation, 36, 13-21.

Betrie, G.D., Mohamed, Y.A., van Griensven, A., Srinivasan, R., 2011. Sediment management modelling in the Blue Nile Basin using SWAT model. Hydrology and Earth System Sciences, 15, 807-818. DOI: 10.5194/hess-15-807-2011.

Cheesman, R.E., 1936. Lake Tana and the Blue Nile an Abyssinian quest. Macmillan and Co., Limited.

Conway, D., 2000. The climate and hydrology of the Upper Blue Nile River. The Geographical Journal, 166, 49-62.

Dagnew, D.C., Guzman, C.D., Zegeye, A.D., Tibebu, T.Y., Getaneh, M., Abate, S., Zemale, F.A., Ayana, E.K., Tilahun, S.A., Steenhuis, T.S., 2015. Impact of conservation practices on runoff and soil loss in the sub-humid Ethiopian Highlands: The Debre Mawi watershed. J. Hydrol. Hydromech, 63, 210-219. DOI: 10.1515/johh-20150021.

Descheemaeker, K., Nyssen, J., Poesen, J., Raes, D., Haile, M., Muys, B., Deckers, S., 2006. Runoff on slopes with restoring vegetation: a case study from the Tigray highlands, Ethiopia. Journal of Hydrology, 331, 219-241.

Dessie, M., Verhoest, N.E.C., Admasu, T., Pauwels, V.R.N., Poesen, J., Adgo, E., Deckers, J.,. Nyssen, J., 2014. Effects of the flood plain on river discharge into Lake Tana (Ethiopia). J. Hydrology, 519, 699-710.
Easton, Z.M., Fuka, D.R., White, E.D., Collick, A.S., Biruk Asharge, B., McCartney, M., Awulachew, S.B., Ahmed, A.A., Steenhuis, T.S., 2010. A multi basin SWAT model analysis of runoff and sedimentation in the Blue Nile, Ethiopia. Hydrology and Earth System Sciences Discussions, 7, 3837-3878.

Engda, T.A., Bayabil, H.K., Legesse, E.S., Ayana, E.K., Tilahun, S.A., Collick, A.S., Easton, Z.M., Rimmer, A., Awulachew, S.B., Steenhuis, T.S., 2011. Watershed hydrology of the (semi) humid Ethiopian Highlands. In: Melesse, A.M. (Ed.): Nile River Basin: Hydrology, Climate and Land Use. Springer Science Publisher, pp. 145162.

Erkossa, T., Wudneh, A., Desalegn, B., Taye, G., 2015. Linking soil erosion to on-site financial cost: lessons from watersheds in the Blue Nile basin. Solid Earth, 6, 765-774.

Fox, G.A., Wilson, G., 2010. The role of subsurface flow in hillslope and stream bank erosion: a review. Soil Science Society of America Journal, 74, 717-733.

Fox, G.A., Wilson, G.V., Simon, A., Langendoen, E.J., Akay, O., Fuchs, J.W., 2007. Measuring streambank erosion due to ground water seepage: correlation to bank pore water pressure, precipitation and stream stage. Earth Surface Processes and Landforms, 32, $1558-1573$.

Frankl, A., Nyssen, J., De Dapper, M., Haile, M., Billi, P., Munro, R.N., Deckers, J., Poesen, J., 2011. Linking long-term gully and river channel dynamics to environmental change using repeat photography (Northern Ethiopia). Geomorphology, 129, 238-251.

Frankl, A., Jacob, M., Haile, M., Poesen, J., Deckers, J., Nyssen, J., 2013. The effect of rainfall on spatio-temporal variability in cropping systems and duration of crop cover in the Northern Ethiopian Highlands. Soil Use and Management, 29, 374-383.

Gao, P., 2008. Understanding watershed suspended sediment transport. Progress in Physical Geography, 32, 243-263.

Gebreegziabher, T., Nyssen, J., Govaerts, B., Getnet, F., Behailu, M., Haile, M., Deckers, J., 2009. Contour furrows for in situ soil and water conservation, Tigray, Northern Ethiopia. Soil and Tillage Research, 103, 257-264.

Gebrermichael, D., Nyssen, J., Poesen, J., Deckers, J., Haile, M., Govers, G., Moeyersons, J., 2005. Effectiveness of stone bunds in controlling soil erosion on cropland in the Tigray highlands, Northern Ethiopia. Soil Use and Management, 21, 287-297.

Girmay G, Singh B, Nyssen J, Borrosen T. 2009. Runoff and sedimentassociated nutrient losses under different land uses in Tigray, Northern Ethiopia. Journal of Hydrology, 376, 70-80.

Guzman, C.D., Tilahun, S.A., Zegeye, A.D., Steenhuis, T.S., 2013. Suspended sediment concentration-discharge relationships in the (sub-) humid Ethiopian highlands. Hydrology and Earth System Sciences, 17, 1067-1077.

Haile, M., Herweg, K., Stillhardt, B., 2006a. Sustainable land management - a new approach to soil and water conservation in Ethiopia. Land Resources Management and Environmental Protection Department, Mekelle University, Ethiopia, and Center for Development and Environment (CDE), University of Bern and Swiss National Center of Competence in Research (NCCR) North-South, Bern, Switzerland.

Haile, M., Herweg, K., Stillhardt, B., 2006b. Sustainable land management-A new approach to soil and water conservation in Ethiopia. Mekelle University, Mekelle, Ethiopia, University of Berne, Berne, Switzerland.

Hairsine, P.B., Rose, C.W., 1992. Modeling water erosion due to overland flow using physical principles: 1 . Sheet flow. Water Resources Research, 28, 237-243.

Haregeweyn, N., Yohannes, F., 2003. Testing and evaluation of the agricultural non-point source pollution model (AGNPS) on Augucho catchment, western Hararghe, Ethiopia. Agriculture, Ecosystems \& Environment, 99, 201-212.

Haregeweyn, N., Melesse, B., Tsunekawa, A., Tsubo, M., Meshesha, D., Balana, B.B., 2012. Reservoir sedimentation and its mitigating strategies: a case study of Angereb reservoir (NW Ethiopia). J Soils Sediments, 12, 291-305.

Haregeweyn, N., Poesen, J., Verstraeten, G., Govers, G., Vente, J., Nyssen, J., Deckers, J., Moeyersons, J., 2013. Assessing the performance of a spatially distributed soil erosion and sediment deliv- 
ery model (WATEM/SEDEM) in Northern Ethiopia. Land Degradation \& Development, 24, 188-204.

Kaba, E., Philpot, W., Steenhuis, T.S., 2014. Evaluating suitability of MODIS-Terra images for reproducing historic sediment concentrations in water bodies: Lake Tana, Ethiopia. International Journal of Applied Earth Observation and Geoinformation, 26, 286-297.

Kebede, S., Travi, Y., Alemayehu, T., Marc, V., 2006. Water balance of Lake Tana and its sensitivity to fluctuations in rainfall, Blue Nile basin, Ethiopia. Journal of Hydrology, 316, 233-247.

Lemma, H., Admasu, T., Dessie, M., Fentie, D., Deckers, J., Frankl, A., Poesen, J., Adgo, E., Nyssen, J., 2017. Revisiting lake sediment budgets: how the calculation of lake lifetime is strongly data and method dependent. Earth Surface Processes and Landforms.

Lieskovský, J., Kenderessy, P., 2014. Modelling the effect of vegetation cover and different tillage practices on soil erosion in vineyards: a case study in Vráble (Slovakia) using WATEM/SEDEM. Land Degradation \& Development, 25, 288-296.

Liu, B.M., Collick, A.S., Zeleke, G., Adgo, E., Easton, Z.M., Steenhuis, T.S., 2008. Rainfall-discharge relationships for a monsoonal climate in the Ethiopian highlands. Hydrological Processes, 22, 1059-1067.

Lyon, S.W., Seibert, J., Lembo, A., Walter, M.F., Steenhuis, T.S., 2005. Geostatistical investigation into the temporal evolution of spatial structure in a shallow water table. Hydrology and Earth System Sciences Discussions, 2, 1683-1716. DOI: 10.5194/hessd-21683-2005.

Mishra, S.K., Singh, V.P., 2004. Long-term hydrological simulation based on the Soil Conservation Service curve number. Hydrological Processes, 18, 1291-1313.

Moges, M.A., Zemale, F.A., Alemu, M.L., Ayele, G.K., Dagnew, D.C., Tilahun, S.A. Steenhuis, T.S., 2016. Sediment concentration rating curves for a monsoonal climate: upper Blue Nile. Soil, 2, 3, 337 349.

Moriasi, D., Arnold, J., Van Liew, M., Bingner, R., Harmel, R., Veith, T., 2007. Model evaluation guidelines for systematic quantification of accuracy in watershed simulations. Trans. ASABE, 50, 885-900.

Rientjes, T., Haile, A., Kebede, E., Mannaerts, C., Habib, E., Steenhuis, T.S, 2011. Changes in land cover, rainfall and stream flow in Upper Gilgel Abbay catchment, Blue Nile basin-Ethiopia. Hydrology and Earth System Sciences, 15, 1979-1989.

Setegn, S.G., Srinivasan, R., Dargahi, B., 2008. Hydrological and sediment yield modelling in Lake Tana basin, Blue Nile Ethiopia. The Open Hydrology Journal, 2, 49-62.

Setegn, S.G., Srinivasan, R., Dargahi, B., Melesse, A.M., 2009. Spatial delineation of soil erosion vulnerability in the Lake Tana Basin, Ethiopia. Hydrological Processes, 23, 3738-3750.

Setegn, S.G., Darfahi, B., Srinivasan, R., Melesse, A.M., 2010a. Modeling of sediment yield from Anjeni-gauged watershed, Ethiopia using SWAT model. J. Am. Water Resour. Assoc., 46, 514-526.

Setegn, S.G., Srinivasan, R., Melesse, A.M., Dargahi, B., 2010b. SWAT model application and prediction uncertainty analysis in the Lake Tana Basin, Ethiopia. Hydrological Processes, 24, 357-367.

Setegn, S.G., Rayner, D., Melesse, A.M., Dargahi, B., Srinivasan, R., 2011. Impact of climate change on the hydroclimatology of Lake Tana Basin, Ethiopia. Water Resources Research, 47, W04511.

SMEC, 2008. Hydrological study of the Tana-Beles sub- basins, Hydrological monitoring network (Review and recommendations). Ministry of Water Resources.

Steenhuis, T.S., Collick, A.S., Easton, Z.M., Leggesse, E.S., Bayabil, H.K., White, E.D., Awulachew, S.B., Adgo, E., Ahmed, A.A., 2009. Predicting discharge and sediment for the Abay (Blue Nile) with a simple model. Hydrological Processes, 23, 3728-3737.

Steenhuis, T.S., Van der Molen, W., 1986. The Thornthwaite-Mather procedure as a simple engineering method to predict recharge. Journal of Hydrology, 84, 221-229.
Tamene, L., Park, S., Dikau, R., Vlek, P., 2006. Analysis of factors determining sediment yield variability in the highlands of northern Ethiopia. Geomorphology, 76, 76-91.

Tebebu, T., Abiy, A., Zegeye, A., Dahlke, H., Easton, Z., Tilahun, S., Collick, A., Kidnau, S., Moges, S., Dadgari, F., 2010. Surface and subsurface flow effect on permanent gully formation and upland erosion near Lake Tana in the northern highlands of Ethiopia. Hydrology and Earth System Sciences, 14, 2207-2217.

Thornthwaite, C., Mather, J., 1955. The water balance. Centerton: Drexel Institute of Technology, 1955. 104 p. Publications in Climatology, 8, 104.

Tilahun, S.A., Guzman, C.D., Zegeye, A.D., Dagnew, D.C., Collick, A.S., Yitaferu, B., Steenhuis, T.S., 2015. Distributed discharge and sediment concentration predictions in the sub-humid Ethiopian highlands: the Debre Mawi watershed. Hydrological Processes, 29, $1817-1828$.

Tilahun, S.A., Guzman, C.D., Zegeye, A.D., Engda, T.A, Collick, A.S., Rimmer, A., Steenhuis, T.S., 2013a. An efficient semi-distributed hillslope erosion model for the subhumid Ethiopian Highlands. Hydrology and Earth System Sciences, 17, 1051-1063. DOI: 10.5194/hess-17-1051-2013.

Tilahun, S.A., Mukundan, R., Demisse, B.A., Engda, T.A., Guzman, C.D., Tarakegn, B.C., Easton, Z.M., Collick, A.S., Zegeye, A.D., Schneiderman, E.M., Parlange, J.Y., Steenhuis, T.S., 2013b. A saturation excess erosion model. Transactions of the ASABE 56, 681695. DOI: $10.13031 / 2013.42675$.

Vanmaercke, M., Zenebe, A., Poesen, J., Nyssen, J., Verstraeten, G., Deckers, J., 2010. Sediment dynamics and the role of flash floods in sediment export from medium-sized catchments: a case study from the semi-arid tropical highlands in northern Ethiopia. Journal of Soils and Sediments, 10, 611-627.

Vijverberg, J., Sibbing, F.A., Dejen, E., 2009. Lake Tana: Source of the Blue Nile. In: The Nile, Springer, pp. 163-192.

Walling, D.E., 2008. The changing sediment load of the Mekong River. Ambio, 37, 3, 150-157.

Wang, S., Fu, B., Piao, S., Lü, Y., Ciais, P., Feng, X., Wang, Y., 2015. Reduced sediment transport in the Yellow River due to anthropogenic changes. Nature Geoscience.

White, E.D., Easton, Z.M., Fuka, D.R., Collick, A.S., Adgo, E., McCartney, M., Awulachew, S.B., Selassie, Y.G., Steenhuis, T.S., 2011. Development and application of a physically based landscape water balance in the SWAT model. Hydrological Processes, 25, 915-925.

Yasir, S., Crosato, A., Mohamed, Y.A., Abdalla, S.H., Wright, N.G., 2014. Sediment balances in the Blue Nile River Basin. International Journal of Sediment Research, 29, 316-328.

Yitbarek, T., Belliethathan, S., Stringer, L., 2012. The onsite cost of gully erosion and cost-benefit of gully rehabilitation: A case study in Ethiopia. Land Degradation \& Development, 23, 157-166.

Yu, B., Rose, C.W., Ciesiolka, C., Coughlan, K., Fentie, B., 1997. Toward a framework for runoff and soil loss prediction using GUEST technology. Aust. J. Soil Res., 35, 1191-1212.

Zegeye, A.D., Steenhuis, T.S., Blake, R.W., Kidnau, S., Collick, A.S., Dadgari, F., 2010. Assessment of soil erosion processes and farmer perception of land conservation in Debre Mewi watershed near Lake Tana, Ethiopia. Ecohydrology \& Hydrobiology, 10, 297-306. DOI: 10.2478/v10104-011-0013-8.

Zeleke, G., 2000. Landscape dynamics and soil erosion process modeling in the north western Ethiopian highlands. African Studies Series A 16. Geographica Bernensia, Berne, Switzerland, 226 p.

Received 28 September 2016 Accepted 4 July 2017 